\title{
Ecology of freshwater shore zones
}

\author{
David L. Strayer · Stuart E. G. Findlay
}

Received: 4 March 2009/Accepted: 18 January 2010/Published online: 9 February 2010

(c) The Author(s) 2010. This article is published with open access at Springerlink.com

\begin{abstract}
Freshwater shore zones are among the most ecologically valuable parts of the planet, but have been heavily damaged by human activities. Because the management and rehabilitation of freshwater shore zones could be improved by better use of ecological knowledge, we summarize here what is known about their ecological functioning. Shore zones are complexes of habitats that support high biodiversity, which is enhanced by high physical complexity and connectivity. Shore zones dissipate large amounts of physical energy, can receive and process extraordinarily high inputs of autochthonous and allochthonous organic matter, and are sites of intensive nutrient cycling. Interactions between organic matter inputs (including wood), physical energy, and the biota are especially important. In general, the ecological character of shore zone ecosystems is set by inputs of physical energy, geologic (or anthropogenic) structure, the hydrologic regime, nutrient inputs, the biota, and climate. Humans have affected freshwater shore zones by laterally compressing and stabilizing the shore zone, changing hydrologic regimes, shortening and simplifying shorelines, hardening shorelines, tidying shore zones, increasing inputs of physical energy that impinge on shore zones, pollution, recreational activities, resource extraction, introducing alien species, changing climate, and intensive development in the shore zone. Systems to guide management and restoration by quantifying ecological services provided by shore zones and balancing multiple (and sometimes conflicting) values are relatively recent and imperfect. We
\end{abstract}

D. L. Strayer $(\bowtie) \cdot$ S. E. G. Findlay

Cary Institute of Ecosystem Studies, P.O. Box AB,

Millbrook, NY 12545, USA

e-mail: strayerd@caryinstitute.org close by identifying leading challenges for shore zone ecology and management.

Keywords Shoreline - Littoral zone - Biodiversity · Ecosystem function $\cdot$ Lakes $\cdot$ Rivers

\section{Introduction}

Shore zones are among the most productive and most threatened habitats on our planet. Natural shore zones are the sole homes of many distinctive plants and animals, and as transition zones between aquatic and terrestrial ecosystems, can contain highly diverse biological communities as well as hot spots of biogeochemical activity. Intact shore zones also regulate exchanges between aquatic and terrestrial ecosystems, contributing to the normal functioning of both. Shore zones can be one of the most valuable parts of the world in terms of the ecological services that they provide-habitat for many species, recreation, harvestable resources, production and processing of organic matter, dissipation of wave energy, flood protection, maintenance of water quality, and dispersal corridors for plants and animals.

Humans have used shore zones intensively for thousands of years, which has greatly reduced their ability to provide these ecological services. Many of the world's great civilizations arose in the shore zone, most of the world's great cities still depend on the shore zones in which they are located, and more than half of the world's population lives in or near the shore zone (Airoldi and Beck 2007). Humans use shore zones for land- and water-based transportation; as a source of water for domestic, industrial, and agricultural use; for waste disposal; as a place to harvest plants, animals, and geologic resources; for recreation and aesthetic 
and spiritual inspiration; and as desirable sites for building homes and factories. Human pressure on shore zones will increase in the future as the human population grows, as an increasing fraction of that population moves into the shore zone and adjacent areas (Airoldi and Beck 2007), as new building is increasingly focused in the shore zone (Glasby and Connell 1999), as economic growth places more demands on shore zones, as increasingly affluent populations demand more water-based recreation, and as engineers work to protect property from rising sea level on oceanic shores (Nicholls et al. 1999; IPCC 2007) and changing water levels on inland waters resulting from climate change.

Thus, ecologists, engineers, managers, and planners will be challenged to maximize ecological functioning while maintaining human uses of shore zones. At present, ecological functioning of shore zones often is neglected in favor of engineering or economic concerns (Ostendorp 2008). We need better designs for engineered structures in the shore zone, better laws to protect the shore zone, better systems of protected conservation areas, and better ways to rehabilitate ecologically degraded shore-zone ecosystems. All of these solutions will require us to understand the functioning of shore-zone ecosystems, both natural and engineered. The purpose of this review is to summarize what is known about the ecological functioning of shorezone ecosystems in fresh water.

\section{The shore zone}

The shoreline is the infinitesimally thin line that separates the water from the land. It is well known that the precise location, length, and shape of the shoreline depends on the scale of the observation (Mandelbrot 1967), but despite these nuances, the definition of the shoreline is clear enough.

It is impossible to offer such a clear, unambiguous definition of the shore zone. In broad terms, the shore zone is the region in which interactions with the land have a strong influence on ecological processes and structures in the water, and vice versa. The ideal definition of the shore zone depends, however, on the subject of the study. A geologist studying sand transport might define the shore zone as extending from the landward limit of active sand dunes to the greatest depth at which waves suspend submarine sands. However, a fish ecologist interested in the use of woody debris by lake-dwelling fishes might define the shore zone as extending a distance of the height of the tallest tree in either direction from the shoreline (i.e., the terrestrial zone which supplies wood to the lake plus the aquatic zone that receives that wood). There is no reason to suspect that different definitions of the shore zone adopted by investigators working on different subjects will be even approximately congruent (cf. Ostendorp 2004). Indeed, previous authors have used several definitions and subdivisions of the shore zone (Fig. 1). We doubt that it will be possible (or even desirable) to reconcile these various systems to reach a single, unambiguous definition of the shore zone that will be useful across all subjects and study sites.

Instead, we propose a broad definition: the shore zone is the region closely adjoining the shoreline in which strong and direct interactions tightly link the terrestrial ecosystem to the aquatic ecosystem, and vice versa. We think is it useful to exclude some kinds of strong aquaticterrestrial interactions from this definition. For instance, it seems unnatural to define the inland forests of the Pacific Northwest as being in the shore zone of the Pacific Ocean, despite the fact that marine-derived nutrients carried by salmon have an important influence on these forests (e.g., Naiman et al. 2002). We do not deny the importance of such long-distance interactions, but they are so spatially incongruent with the other interactions between the Pacific Ocean and the land (e.g., wave wash, wrack deposition, salt spray) and so far removed from the use of "the shore" in common language that it would seem to overstretch the idea of the shore zone to include them.

Because of the enormous diversity of shore zones, and because many kinds of shore zones have been reviewed well by others, we focus here on the ecology of freshwater shore zones in which wave energy is an important factor. This includes lakes and rivers large enough to have substantial waves driven by the wind or from recreational boating or commercial shipping; very roughly, lakes larger than $\sim 10$ ha and rivers more than $100 \mathrm{~m}$ wide.

We exclude marine shore zones, because they have been very well treated by others (e.g., Denny 1988; Paine 1994; Bertness 1999; Brown and McLachlan 2002; Thompson et al. 2002; McLachlan and Brown 2006; Airoldi and Beck 2007; National Research Council 2007), and because they are quite different from their freshwater counterparts. Marine shore zones often are subject to tides and high wave energy, and support a distinctive biota. We also exclude freshwater shore zones that are subject to low wave energy. Shore zones of smaller bodies of water are extensive and ecologically important, but have a different character from wave-swept shore zones. These include the riparian zones of small streams and rivers, as well as many wetlands, which were recently addressed by Naiman et al. (2005) and Mitsch and Gosselink (2007). Although we do not address marine shore zones or freshwater shore zones with low wave energy in detail, we bring in data and ideas from these habitats where they are relevant. 
Fig. 1 Examples of three classifications of the shore zone, showing the diversity of approaches and defining variables. From top to bottom: Hutchinson's (1967)

classification of lake zonation; Ostendorp et al.'s (2004)

classification of the shore zone of lakes; McLachlan's (1983)

classification of zonation along a marine sandy beach
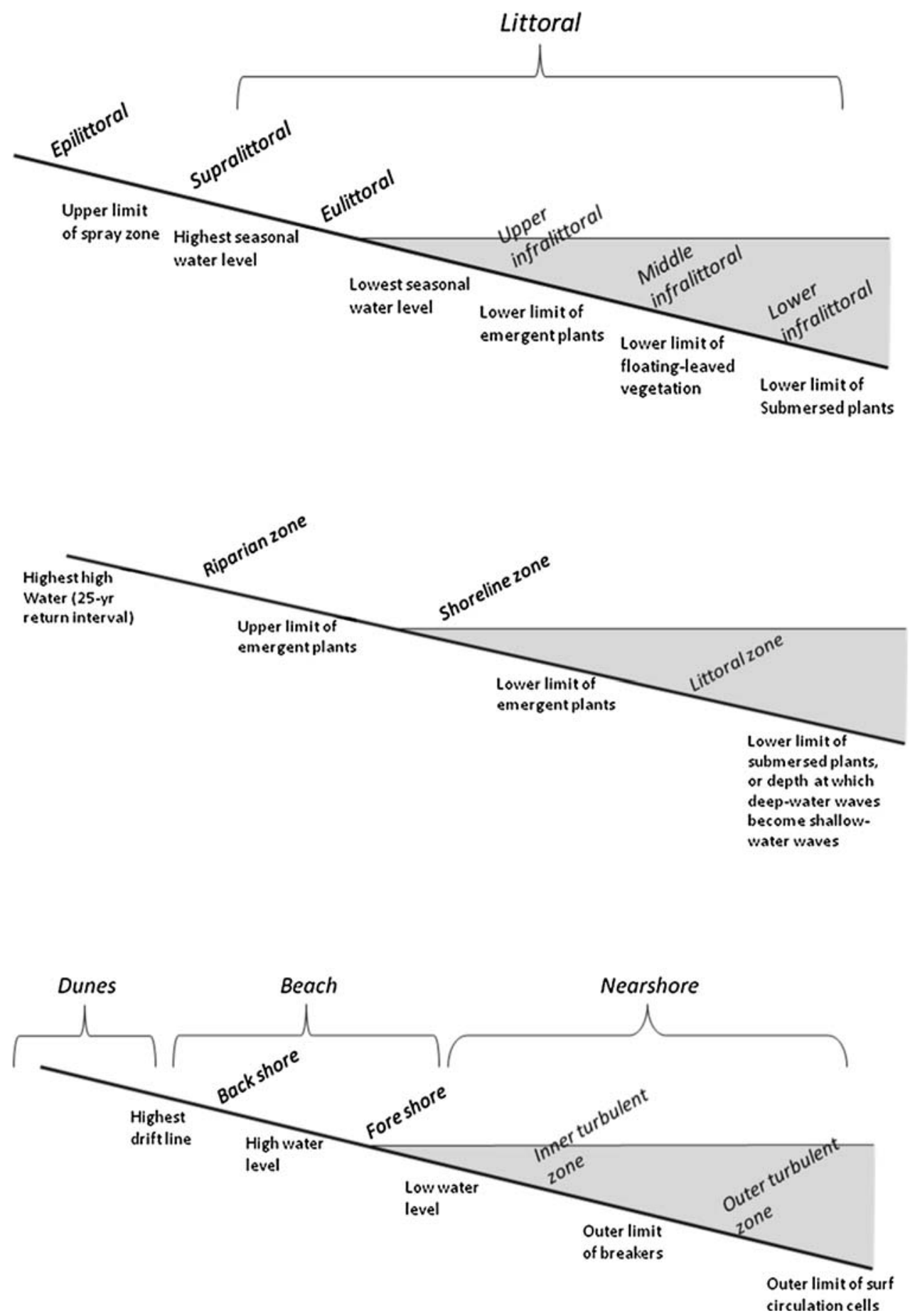

\section{Special characteristics of the shore zone}

Before describing the ecological functions performed by the shore zone, it is worth emphasizing some of the unusual characteristics of the shore zone: it is a phase boundary between land, air, and water; it is a zone of energy dissipation; it is a characteristically heterogeneous environment; and it often is a large, spatially continuous habitat and therefore a dispersal corridor for plants and animals.
The shore is a phase boundary between land, water, and air

The shore zone is defined as a boundary region between land and water (and of course, air). The juxtaposition of these three realms has several important ecological consequences. Two of them, energy dissipation at the shoreline and habitat heterogeneity, are important enough to be discussed individually below. In addition, shore zones are 
sites where buoyant materials (driftwood, wrack, plastic trash, ice, and hydrophobic liquids such as oil) accumulate. Floatable materials can be washed into the shore zone more or less permanently, or they can be very transient, washing up in one storm and leaving a few days later in the next. The expansion and contraction of the sheet of ice covering a lake or river can bulldoze shoreline materials into a ridge along the shore and destroy vegetation (Begin and Payette 1991). Alternatively, when the ice sheet breaks up, winds, currents, and flood waters can push large mounds of ice onto the shoreline, moving materials and destroying plants and animals. Shallow-water sediments may freeze into an ice sheet and be rafted away when the ice breaks up in the spring (Reimnitz et al. 1991; Dionne 1993). Thus, ice can be an important geomorphic agent along shore lines in cold regions (Forbes and Taylor 1994).

The shore is a zone of energy dissipation

Waves break on the shore, dissipating a large amount of energy in a focused area. This energy dissipation has several important ecological consequences-it suspends shallow-water sediments (making them available for transport by currents and decreasing water clarity in the shore zone), erodes the shore, increases turbulence, drives water movement through nearshore sediments, and produces strong and highly variable forces on the organisms that live in the surf zone (Denny 1988). All of these processes affect biodiversity and biogeochemical processes in the shore zone. Especially if water levels fluctuate, wave energy is part of the dynamic by which sediments and organic matter are suspended, transported, deposited, and temporarily stored in the shore zone.

The importance of energy dissipation varies enormously across time and space in freshwater shore zones. Wave energy is negligible in small or sheltered fresh waters, but can reach values as high as hundreds of kilowatts per meter of shoreline during storms on large lakes (Fig. 2). Wave energy tends to be very variable over time in freshwater shore zones, falling to zero for part of the time in all freshwater shorelines, in contrast to marine shores that are subject to regular, incessant swells. Some shorelines (e.g., gently sloping beaches) dissipate nearly all incident wave energy, whereas others (e.g., vertical seawalls) reflect nearly all incident wave energy.

The shore zone is a heterogeneous environment

Shore zones are always regions of high environmental contrast and heterogeneity (e.g., Pieczyńska 1972; Amoros and Bornette 2002; Robinson et al. 2002; Ostendorp et al. 2004; Arscott et al. 2005). This stems partly from the simple juxtaposition of a terrestrial ecosystem with an aquatic

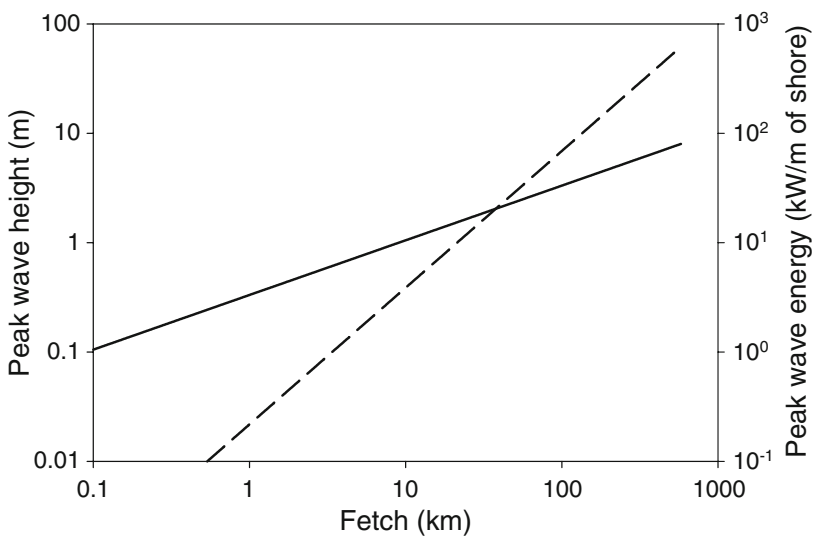

Fig. 2 Very rough estimates of peak wave heights offshore (solid line) and peak wave energy impinging on shorelines (dashed line) as a function of fetch. Axes are logarithmic. Based on formulas of Denny (1988), assuming that wave height $=0.05$ wavelength (Wetzel 2001)

ecosystem, and partly from large variations in inputs of physical energy. By definition, shore zones contain both aquatic and terrestrial parts, and these adjacent parts have highly contrasting biotas and environmental conditions (e.g., temperature, redox potential, physical forces, disturbance regimes). In particular, shore zones frequently contain closely juxtaposed aerobic and anaerobic zones. As in other ecosystems, the biota and underlying geology contribute to additional environmental heterogeneity. Most importantly, the high physical energy (waves, currents) in the shore zone interacts with these geological and biological structures to produce an environment that is highly heterogeneous on all spatial scales, from scour and deposition around a rush stem to islands formed in the lee of woody debris. The heterogeneity of the shore zone includes many environmental variables, including substratum granulometry, water and soil chemistry, temperature, light, disturbance rates, predation rates, amount and quality of organic matter, rates of water movement, and many others. Although the most obvious direction of heterogeneity is across the shore zone, heterogeneity along the shore zone may be large and ecologically important, particularly if there is a directional flow of water or if the underlying geology is variable.

Shore zones usually are also regions of high temporal variability, as a result of temporal variation in water level, wave energy, biological activity, and climatic conditions. Again, this temporal heterogeneity occurs across all timescales, from ephemeral changes in physical energy and sediment suspension in a breaking wave, to annual cycles of biological activity and soil biogeochemistry associated with flooding, to long-term evolution of shore zone geomorphology following changes in climate or land use in the watershed. All of these forms of temporal heterogeneity shape the ecology of the shore zone. 
The shore zone is a dispersal corridor

Shorelines are corridors for movement and dispersal of biota, for several reasons. First, many species have their main habitats in the shore zone. For these species, habitats outside the shore zone are inhospitable, so dispersal takes place chiefly within the shore zone. Second, shorelines are more or less impassible boundaries for many members of both the aquatic and terrestrial biota. When such species move across the landscape or through the water and encounter a shoreline, they must turn and follow the shoreline (or retrace their path), resulting in a concentration of migrating individuals along the shore zone. Third, the physical structure of the shore zone often facilitates dispersal. Shore zones along large lakes and especially rivers are physically continuous over long distances. Further, many species of terrestrial plants and animals are dispersed by currents, either as floating seeds (or other propagules) or on rafts of floating debris or ice (e.g., Hill et al. 1998; Nilsson and Svedmark 2002; Jansson et al. 2005; Thiel and Gutow 2005). As a result, breaks in the shore zone, whether natural or human-made, can seriously impede the movement of the biota and fragment populations.

\section{Ecological services provided by shore zones}

Shore zones perform many ecological functions that humans value ("ecological services"). We briefly review the most important and well-studied of these ecological services, describing the importance, regulating factors, and human impacts on each.

\section{Support of biodiversity}

One of the most important ecological functions that shore zones provide is to support biodiversity. This includes species that are harvested by humans (waterfowl, fish, shellfish, timber, reeds, etc.), species that we value for recreational or aesthetic purposes (birds, catch-and-release fisheries, wildflowers), imperiled species that live chiefly in the shore zone, and species that perform important biogeochemical functions (e.g., riparian vegetation).

Shore zones can support a rich biota of both aquatic and terrestrial species, including bacteria, fungi, protozoans, plants, and animals. Barren, frequently disturbed shore zones (such as those bordering hydropower reservoirs) may have a poor biota, but many kinds of natural shore zones have remarkably rich biotas, containing a very large fraction $(>25 \%)$ of all of the species in the regional species pool (e.g., Obrdlík et al. 1995; Nilsson and Svedmark 2002). There are no complete inventories of the biotas of freshwater shore zones, but such rich zones are likely to support hundreds to thousands of species, excluding bacteria. Shore zone habitats are highly varied, and different kinds of shore zone support different kinds of plants and animals (e.g., Bänziger 1995; Madjeczak et al. 1998; Lewin et al. 2004; Brauns et al. 2007). Consequently, it is difficult to make any generalizations about the "typical" shore zone biota. Nevertheless, we can make a few interesting general points about the shore zone biota.

Many species are more or less restricted to the shore zone, or at least depend completely on the shore zone for part of their life cycle. These shore zone endemics include many plants (e.g., dune grasses, floodplain specialists, most aquatic plants), invertebrates (including specialists that depend on shore zone plants), and vertebrates (e.g., many fishes, amphibians, turtles, shorebirds, terns, waterfowl). The transformation of shore zones by humans has especially serious consequences for the continued survival of these species; it is no surprise that several of these shore zone specialists in the United States are now extinct or imperiled (e.g., Pitcher's thistle Cirsium pitcheri, the decurrent false aster Boltonia decurrens (Smith et al. 1998), the piping plover Charadrius melodus, and the least tern Sterna antillarum).

The terrestrial side of the shore zone often contains large numbers of predators and scavengers that feed on wrack or carrion that is washed up onto the shore, or on emerging aquatic insects. This guild includes predatory arthropods like spiders and carabid beetles (e.g., Polis and Hurd 1996; Kleinwächtler et al. 2005; Paetzold et al. 2005), insectivorous birds and bats (Gray 1993), scavenging invertebrates like dipterans, isopods, and grasshoppers (e.g., Backlund 1945; Behbehani and Croker 1982; McLachlan 1983, 1985; Bastow et al. 2002), predatory and scavenging mammals (Moore 2002; Carlton and Hodder 2003), and others. This subject will be discussed in more detail in the section on accumulation and processing of organic matter.

Wave-swept shores support many organisms that usually are thought of as stream-dwellers, such as heptageniid mayflies, stoneflies, elmid beetles, pleurocerid snails, and filamentous green and red algae (Brinkhurst 1974; Barton and Hynes 1978; Brittain and Lillehammer 1978; Dall et al. 1984; Meadows et al. 2005). This group of animals is especially conspicuous at sites where wave energy is high, such as the exposed shores of the Laurentian Great Lakes.

\section{Controls on biodiversity}

Much has been written about which features of the shore zone determine which species live there, and ecologists have identified a very wide range of controlling factors. Some factors that surely are important in controlling the distribution and abundance of species in the shore zone (e.g., climate) have received little attention. Here, we 
briefly review some of the factors that have received most attention from shore zone ecologists.

\section{Physical complexity}

Physically complex shore zones usually support a richer biota than simple ones. Comparisons of different kinds of shore zones usually show that density (Jenkins and Wheatley 1998; Barwick 2004; Barwick et al. 2004; Toft et al. 2007), biomass (Barwick 2004; Lewin et al. 2004), body size (Madjeczak et al. 1998), or species richness (Jenkins and Wheatley 1998; Jennings et al. 1999; Barwick 2004) of fishes is greater in structurally complex habitats than in simple habitats (Fig. 3). Working at larger spatial scales, Benson and Magnuson (1992) reported that $\beta$ diversity (site-to-site variation in species composition) of fish communities in Wisconsin lakes was correlated with the amount of physical heterogeneity across sites. Further, structurally complex habitats may support distinctive communities of fish (Jenkins and Wheatley 1998; Madjeczak et al. 1998; Long and Walker 2005). Growth rates of fishes may be higher in structurally complex habitats as well; Schindler et al. (2000) found that the growth rate of bluegills was correlated with the amount of coarse woody debris in lakes (Fig. 3), and Sass et al. (2006) showed that growth rates of largemouth bass fell when woody debris was experimentally removed from a lake. There are exceptions to these patterns, of course. Juvenile Chinook salmon were more likely to be found over gravel bottoms than in structurally complex riprap in a western reservoir (Garland et al. 2002), consistent with the observation that added artificial structure rarely enhances local densities of salmonids in lakes (Bolding et al. 2004).

Experimental additions of structure usually increase the local density (Barwick et al. 2004; Bolding et al. 2004), spawning (Vogele and Rainwater 1975), and growth and survival (Bolding et al. 2004) of fishes. The strength of this effect depends on the species of fish and the amount of structure available in the surrounding area (Bolding et al. 2004; Wills et al. 2004). There is an active debate about whether such artificial structures actually increase population size, or merely attract fish from other areas. Added structure may also encourage anglers to overharvest fishes, lead to stunting of prey species, be ugly, or pose a hazard to
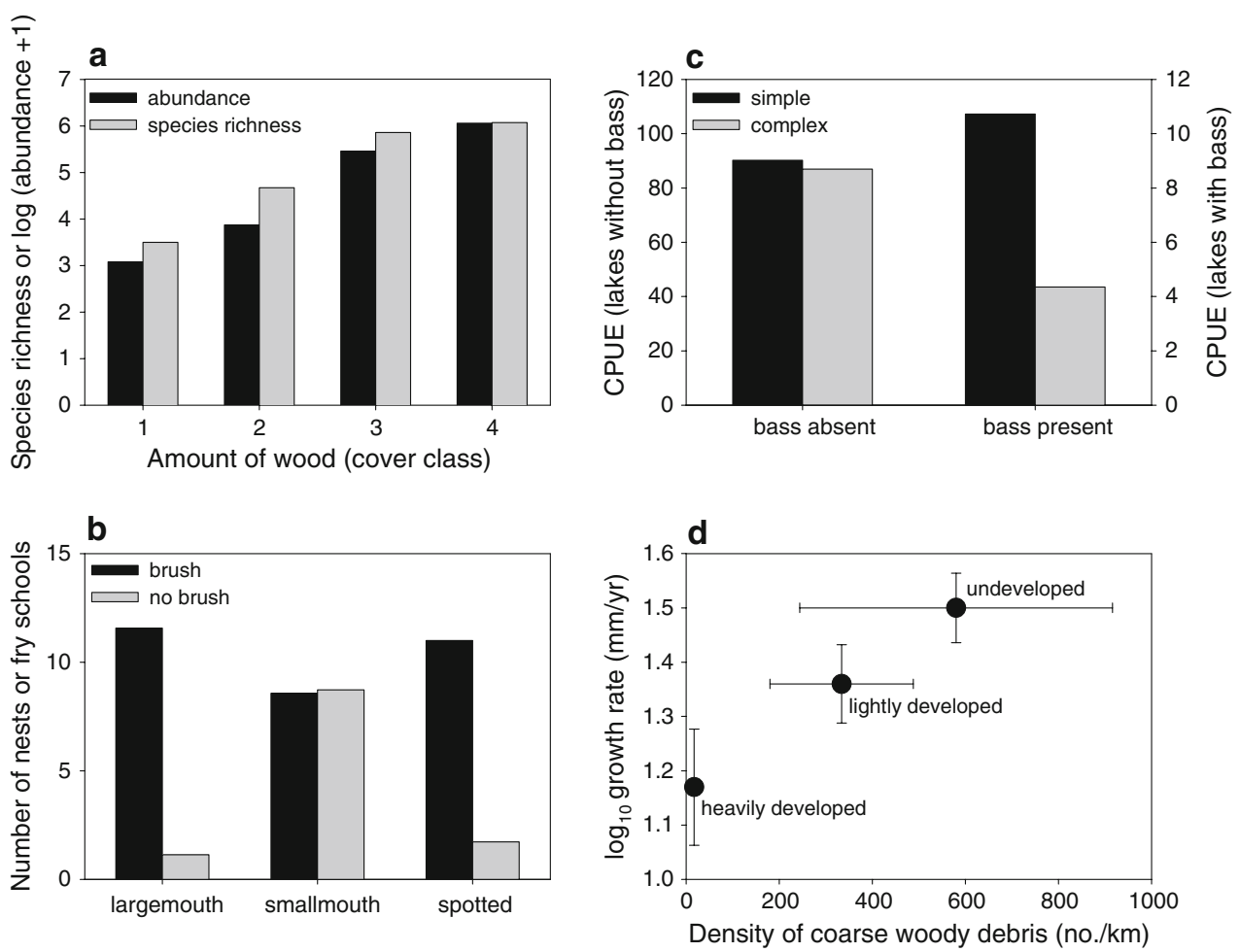

Fig. 3 Responses of fishes to structural complexity in the shore zone; a abundance and species richness of fishes as a function of the density of large wood (cover classes as follows: class 1, no wood; class 2, 0 $5 \%$ cover of wood; class 3,5-15\% cover of wood, class $4,>15 \%$ cover of wood) in French rivers (Piégay 2003); b numbers of nests plus schools of young fry of three species of black bass (Micropterus) in Bull Shoals Reservoir along shores with and without

experimentally added brush piles, from data of Vogele and Rainwater (1975); c numbers of small fishes using simple and complex littoral habitats in Ontario lakes with and without smallmouth bass, from data of MacRae and Jackson (2001); d reductions in density of coarse woody debris and growth rates of bluegills $( \pm 1 \mathrm{SD})$ in Wisconsin lakes with increasing human development, from Schindler et al. (2000) 
navigation, so fisheries managers must carefully consider whether adding structure will help them attain their goals for recreational fisheries (Bolding et al. 2004).

Conversely, experimental removal of structure may harm fish populations. Sass et al. (2006) removed most of the coarse woody debris from half of a Wisconsin lake, and found that populations of yellow perch fell drastically. (Because this experiment covered an entire lake basin, we know that populations of perch actually fell, not just moved to other areas.) In response to the loss of this important prey item, predatory largemouth bass shifted their diets, and their growth rates fell.

Habitat structure interacts with other factors in interesting ways. For example, MacRae and Jackson (2001) found that fish densities were higher in structurally complex habitats only in lakes where a large predator (smallmouth bass) was present (Fig. 3). Likewise, Wolter and Arlinghaus (2003) suggested that structure could reduce the deleterious effects of commercial navigation on nearshore fish communities by providing physical refuges against wakes and currents. It therefore seems likely that the per-structure value of structural complexity to fish is greatest in habitats where physical forces are large, predators are abundant, and structure is scarce.

Evidence on the effects of structural complexity on other organisms is consistent with, but scarcer than, data on fish. Structural complexity or high spatial heterogeneity is typically correlated with high densities (Lewin et al. 2004; Kostylev et al. 2005) or species richness (Moon 1934; Le Hir and Hily 2005; Kostylev et al. 2005; Moschella et al. 2005; Brauns et al. 2007) of aquatic invertebrates. Just as with fish, structurally complex shore zones protect invertebrates from the damaging forces of waves (Gabel et al. 2008). On the terrestrial side of the shore zone, Paetzold et al. (2008b) found that channelization, which simplifies the structure of the shore zone, reduced abundance and richness of terrestrial arthropods, and some vertebrates preferentially use complex shore zones (e.g., Stickney et al. 2002). Structurally complex shore zones also support rich plant communities (Fig. 4; Everson and Boucher 1998; Pollock et al. 1998; Naiman et al. 2005). In addition to these specific studies, many authors (e.g., Obrdlík et al. 1995; Nilsson and Svedmark 2002; Arscott et al. 2005; Brauns et al. 2007) have made the general claim that high physical heterogeneity of the shore zone is responsible for its high biodiversity, without offering direct evidence.

A few studies have investigated the details by which physical complexity affects the biota. Le Hir and Hily (2005) suggested that species richness was not driven by physical complexity per se, but rather by the provision of special microhabitats (e.g., cavities) that support particularly distinctive or rich biotic communities (cf. Chapman and Bulleri 2003). Some studies have suggested that the

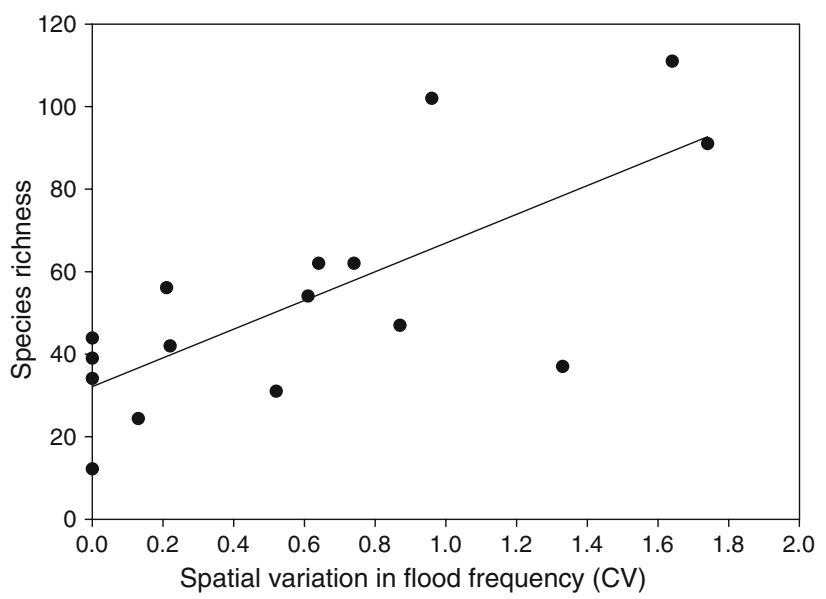

Fig. 4 Plant species richness increases with structural complexity (topographic variation, measured as spatial variation in flood frequency) on floodplains in Alaska $\left(r^{2}=0.52, P<0.01\right.$; Pollock et al. 1998)

size of the roughness elements is related to the size of the organisms that inhabit the shore zone. Thus, the size of fish that use artificial structures depends on the size of the interstitial spaces that these structures provide (Bolding et al. 2004), and small-bodied invertebrates were especially important on structurally complex marine shores that contained many small crevices (Kostylev et al. 2005).

\section{Hydrologic regime}

The hydrologic regime, i.e., the pattern of change in water level over time, strongly influences the composition and activities of the shore zone biota. Shore zone vegetation is tied in several ways to the hydrologic regime (Keddy and Reznicek 1986; Hill et al. 1998; Johnson 2002; Coops et al. 2004; Strang and Dienst 2004; Van Geest et al. 2005). Cottonwoods and other important shore zone plants germinate and establish on exposed soils (Keddy and Reznicek 1986; Nishihiro et al. 2004; Naiman et al. 2005). Saturated, reduced soils produced by high water levels can kill terrestrial vegetation such as shrubs, which would otherwise shade out herbaceous plant species near the water's edge. High water levels also reduce light penetration to underwater sediments, reducing growth rates or killing light-limited submersed aquatic vegetation. Prolonged low water levels can kill vegetation through desiccation. Many plants of the shore zone are thus adapted to moderately fluctuating water levels, which may maximize the extent and species richness of plant cover in the shore zone (Keddy and Reznicek 1986; Hill et al. 1998). Species richness and the area occupied by aquatic plants can be reduced by decreasing, increasing, or changing the seasonal pattern of water-level fluctuations (Hill et al. 1998). Thus, Keddy and others (Keddy and Reznicek 1986; 
Hill et al. 1998) have suggested that the hydrological regime is a master variable that controls the character of the shore zone vegetation (Fig. 5).

Shore zone animals also are affected by the hydrologic regime. Predictable changes in water level allow animals to access different habitats over the course of the year. For example, fishes such as northern pike and yellow perch spawn on seasonally flooded vegetation (Wilcox and Meeker 1992; Farrell 2001) or forage in floodplains (Junk et al. 1989). Amphibians and many other species live in habitats such as shore zone pools whose very existence depends on water-level fluctuations (Robinson et al. 2002). On the other hand, unpredictable changes in water levels can make parts of the shore zone unsuitable for animals or kill them outright. Bowers and de Szalay (2005) suggested that irregular fluctuations in water level resulting from wind-driven seiches kept zebra mussels from colonizing shallow substrates along the shore of Lake Erie. Winddriven waves or wakes can strand young fish on the shore and dewater nests (Adams et al. 1999; Wolter and Arlinghaus 2003). The same effects can be produced by rapidly falling water levels downstream of peaking hydropower dams (Cushman 1985). Conversely, rapid rises in water level, whether natural or anthropogenic, can drown terrestrial animals along the shore (Moon 1935), and Paetzold et al. (2008b) found lower abundance and species richness of riparian arthropods along the shores of rivers with peaking hydropower dams.

As a result of the close relationship between shore zone hydrology and the biota, human-induced changes in shore zone hydrology may lead to rapid and profound changes in the biota. Regulation by hydropower dams changed species composition and reduced species richness of shore zone vegetation along Swedish rivers (Nilsson et al. 1991). Shore zones with artificially stabilized water levels may have lower species richness and higher cover of the invasive plants than those with more natural hydrology (Hill et al. 1998; Van Geest et al. 2005; Boers and Zedler 2008). Bunn and Arthington (2002) suggested that artificially altered hydrologic regimes generally favor alien species. Human regulation of water levels, whether resulting in increased or decreased variability in water levels, also has deleterious effects on fish, waterfowl, and mammals of the shore zone (e.g., Wilcox and Meeker 1992; Farrell 2001).

\section{Elevation (or bathymetry)}

Biological communities and distributions change regularly along an elevational gradient (or its underwater equivalent, the bathymetric gradient), from offshore waters onto the shoreline, and then upslope into upland communities (Fig. 6; Šapkarev 1975; Dall et al. 1984; Keddy and Reznicek 1986; Strayer and Smith 2000; Bulleri and Airoldi 2005). This elevational zonation is so universal and conspicuous that almost all subdivisions of the shore zone are based on elevation (Fig. 1). Elevation is an indicator for changes in many variables that affect the biota, such as frequency and timing of inundation or desiccation; grain size, nutrient and organic content, and redox state of soils and sediments; intensity of predation and other biological interactions; frequency and intensity of disturbance by different agents; and inputs of organic matter from aquatic primary production, terrestrial primary production, and wrack deposition (Fig. 7). As a result, there frequently is a
Fig. 5 Hypothesized relationships between withinand among-year water-level fluctuations and shoreline vegetation in Nova Scotia (modified from Hill et al. 1998). The stippled area shows the floras with the highest species richness

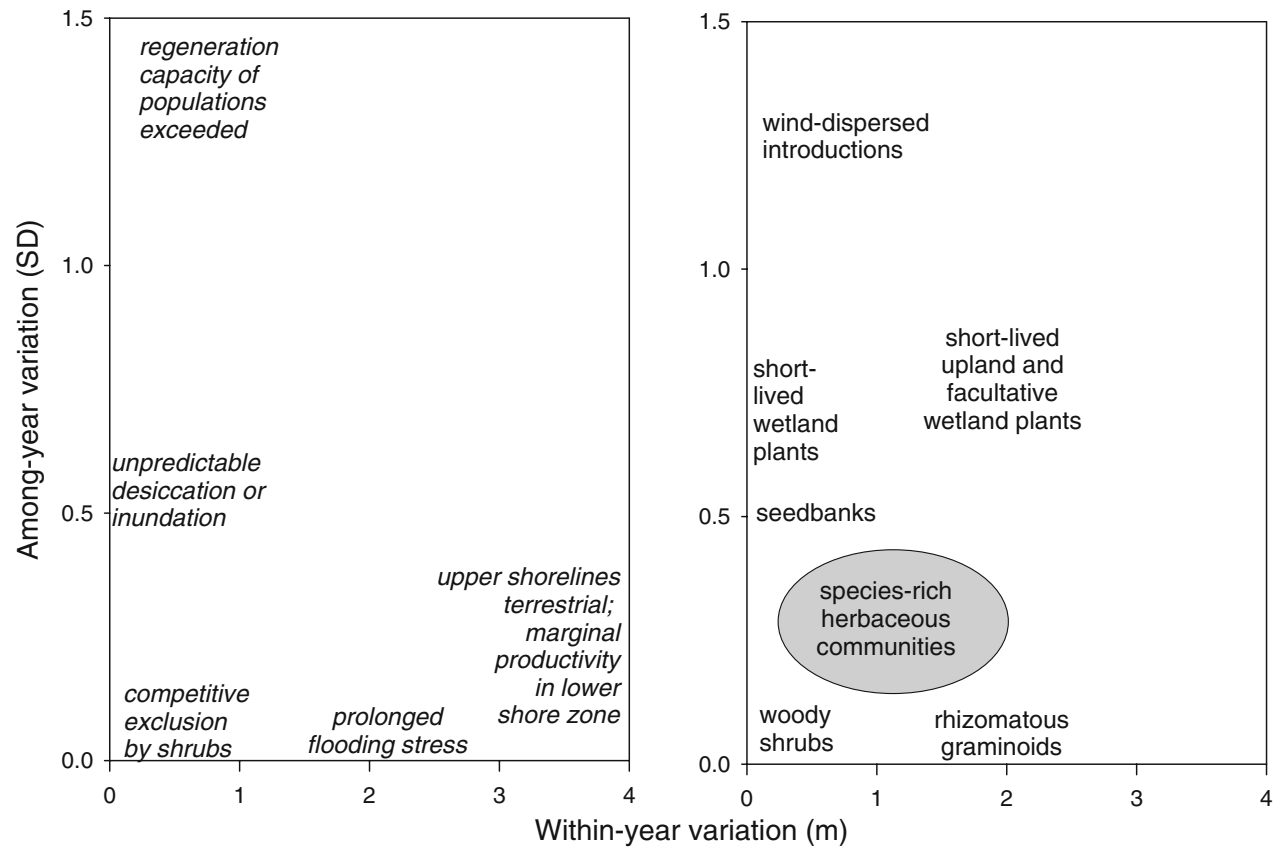


Fig. 6 Density of different kinds of invertebrates (+1SE) along a rocky shoreline in the freshwater tidal Hudson River, as a function of elevation (Strayer and Smith 2000).

"High" $38 \mathrm{~cm}$ above mean low water level, "mid" mean low water level, and "low" $38 \mathrm{~cm}$ below mean low water level. Note the different scales along the $y$ axes of the different panels
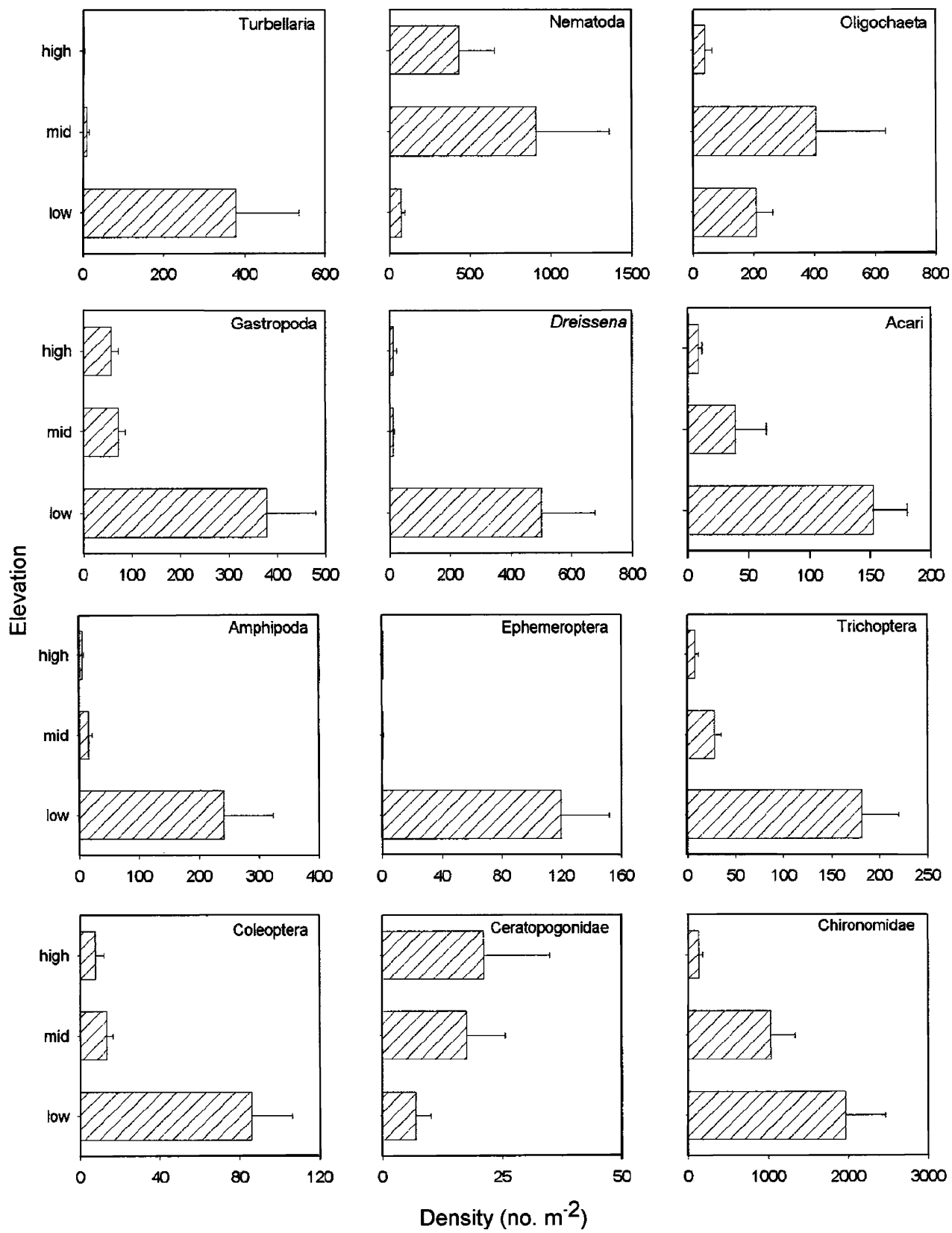

regular zonation of vegetation across the shore zone, from woody plants, to emergent graminoid species such as $T y$ pha (cattail) and Phragmites (common reed) around the shoreline, to low-growing rosette plants just below the shoreline, to floating-leaved species such as Nymphaea (white water lily), Nuphar (spatterdock), and some of the Potamogeton spp. (pondweeds), and finally to fully submerged vascular plants, charophytic algae, and mosses. Because vegetation has such strong effects on animal communities and biogeochemical processes, this vegetational zonation contributes to zonation of many other ecological properties along the elevational gradient.
Slope, a variable closely related to the elevational gradient, may also affect shore zone biodiversity. It is perhaps obvious that slope is important because it determines the width and therefore the area of the shore zone (Fig. 8), which are centrally important to many ecological functions. Slope can also determine the suitability of the shore zone for organisms, for instance as nest or foraging sites for birds (Maccarone et al. 1993; Neuman et al. 2008).

While coarse-scale elevational profiles have received the most attention from ecologists, local elevations (i.e., mesoto microscale roughness) also strongly affect shore zone biodiversity (Fig. 4). For instance, Chapman and Bulleri 


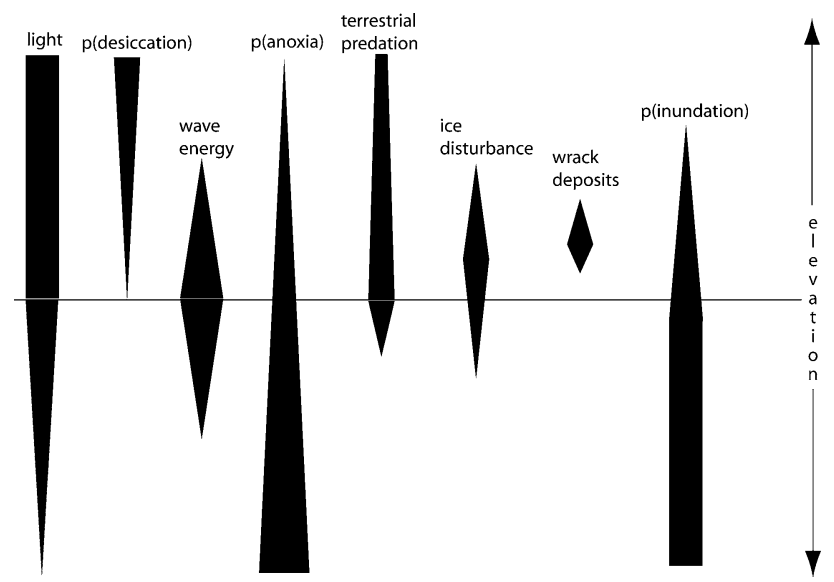

Fig. 7 Cartoon showing how some important controls on biodiversity vary with elevation along the shore zone. The horizontal line is the mean water level. This diagram is not comprehensive (i.e., many factors are omitted) and is very approximate

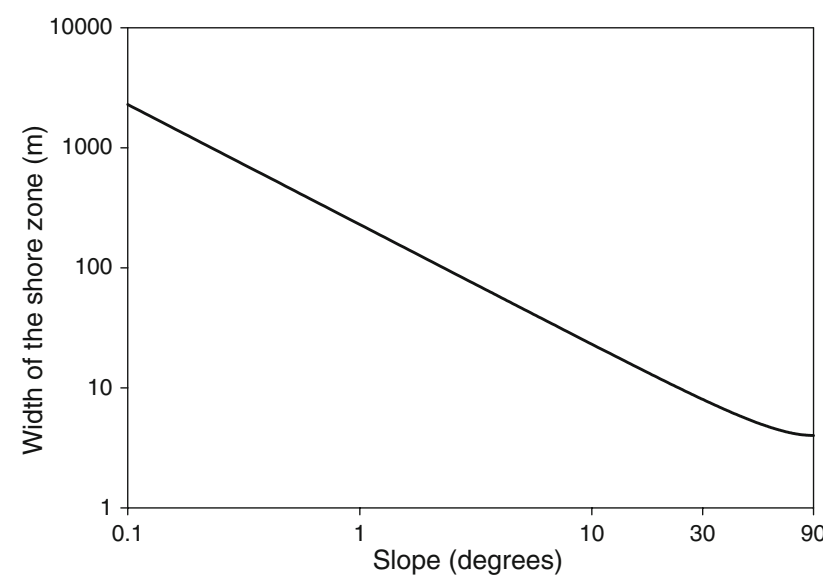

Fig. 8 An example showing how the slope of the shore zone influences its width and area. In this example, the shore zone is defined as the region extending from the $-2 \mathrm{~m}$ contour to the $+2 \mathrm{~m}$ contour. Flat shore zones are very wide, whereas steep shore zones (like those typically made by humans) are very narrow. Both axes are logarithmically scaled

(2003) suggested that one of the main reasons that constructed sandstone seawalls support different species from natural sandstone shores is that the latter contain small pools and crevices that are absent from the seawalls. Likewise, small shoreline pools lying just landward of the lake shore support a rich biota and are metabolically very active (Pieczyńska 1972).

Human actions that change the large-scale shore zone profile or small-scale roughness are likely to have profound effects on the distribution and abundance of species within the shore zone. Such actions, including dredging, filling, and grading, are very common, and probably represent one of the major human impacts on shore zone ecosystems.

\section{Exposure and disturbance}

Many studies point to the importance of exposure in determining the character of the shore zone biota, although this variable is rarely defined and even more rarely measured. Generally what is meant is exposure to the forces of wind and waves (or sometimes currents). Although there are devices to measure exposure as either peak wave energy (Bell and Denny 1994; Guinez and Pacheco 1999) or dissolution rate of a substance such as gypsum (Petticrew and Kalff 1991; Thompson and Glenn 1994; Porter et al. 2000), these methods are rarely used in fresh water. Instead, exposure usually is estimated by measuring the wind fetch at a site (Keddy 1982; Brodersen 1995; Ekebom et al. 2003), if it is estimated at all. Exposure acts as a disturbance (e.g., Keddy 1983) that dislodges or kills organisms. High wind and wave energy also can winnow fine particles out of sediments, thin benthic boundary layers and drive mass flow of water and solutes (e.g., oxygen) through sediments, increase turbulent mixing in the water column, increase passive dispersal of organisms and nonliving particles, and overwhelm the swimming or flying abilities of animals.

Many biologists have noted that the composition of the shore zone biota varies along exposure gradients (Fig. 9; Moon 1934; Keddy 1982, 1983; McLachlan 1983; Dall et al. 1984; Kennedy and Bruno 2000). Rooted aquatic plants often are absent from nearshore areas of highly exposed sites (Chambers 1987) because they are uprooted, damaged, or grow poorly (e.g., Coops et al. 1991, 1994; Doyle 2001). The density and species richness of marine invertebrates is lower on reflective beaches than on dissipative beaches (Fig. 13; Brazeiro 2001; Brown and McLachlan 2002), presumably as a result of the disturbance regime. It is otherwise difficult to generalize about the effects of exposure except to note that species composition usually varies along an exposure gradient, and that numbers and species richness of organisms may be low at highly exposed sites. In this latter respect, freshwater shores may differ from their marine counterparts, in which even very highly exposed shores support a rich and distinctive biota, at least on stable bedrock or boulders. There seems to be no close freshwater equivalent to the biota of exposed marine rocky shores. Some ecologists (Keddy 1983; Tabacchi et al. 1996) have suggested that species richness should peak at intermediate levels of exposure, but this idea seems not to have been accepted as generally true (Riis and Hawes 2003; McClintock et al. 2007).

Several other variables interact with exposure to affect biological distributions in the shore zone. Although finegrained sediments support high densities of macrofauna in sheltered sites (e.g., McLachlan 1983), they can be very poor in highly exposed sites (Barton and Hynes 1978), 


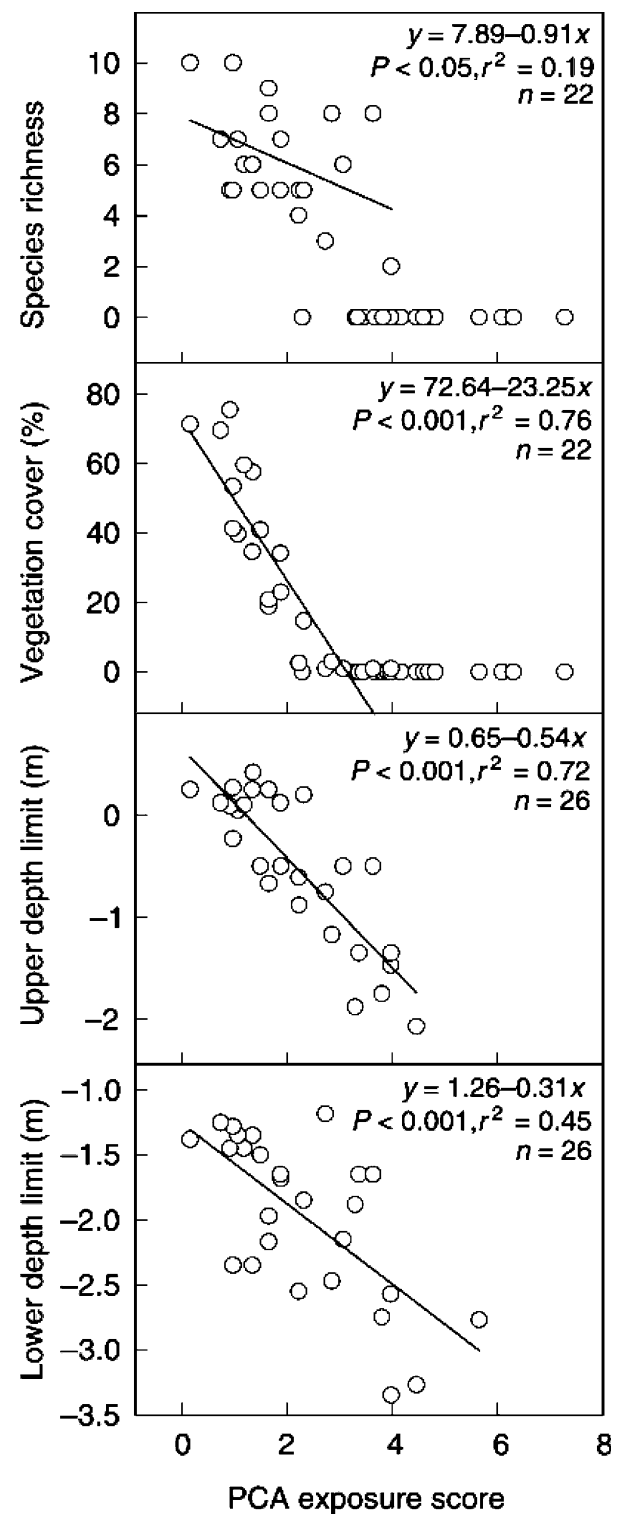

Fig. 9 Characteristics of "low mixed vegetation" in the shore zone of Lake Wanaka, New Zealand, as a function of exposure (Riis and Hawes 2003). Species richness and cover are estimated for the region between $25 \mathrm{~cm}$ above median water level to $1 \mathrm{~m}$ below median water level; sampling transects were placed where maximum vegetation cover occurred within a 50-m long section of shore

presumably because they are stable in sheltered sites but mobile in exposed sites. Thus, the stability of a sediment may be more important than its grain size or the exposure of the site per se. As already suggested, provision of physical shelter may have much greater effects on an exposed shore than on a sheltered shore. Access to quietwater areas during storms or floods may allow the biota to survive these events (e.g., Quist et al. 1999; Rempel et al. 1999). Likewise, the effects of exposure may depend on the biota of a site, as some plants and sessile animals are able

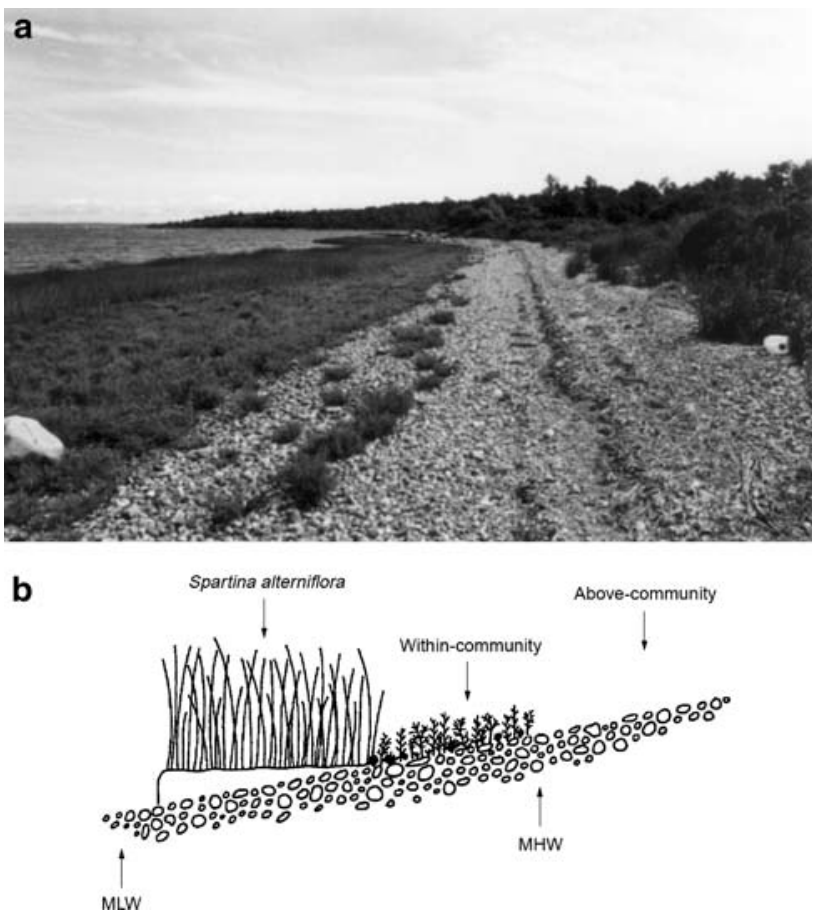

Fig. 10 Vegetational zonation along a marine cobble beach, showing the colonization of the shore zone by forbs just landward of a Spartina (cordgrass) bed, which stabilizes the cobble sediments (Kennedy and Bruno 2000)

to ameliorate the effects of exposure for other organisms (Fig. 10; Brodersen 1995; O'Donnell 2008).

Disturbances other than wind and wave action also are important. Ice and low temperatures can be important agents of disturbance along cold shorelines (Dall et al. 1984; Begin and Payette 1991; Pugh and Davenport 1997). The importance of flooding and desiccation has already been discussed. Disturbances caused by humans (e.g., recreational vehicles) are an important factor in modern shore zones, and will be discussed in a later section on human impacts on the shore zone.

Species richness or density of aquatic animals may be reduced in very shallow water (e.g., Brinkhurst 1974; Šapkarev 1975; Burlakova and Karatayev 2007), presumably as a result of disturbance by waves, ice, or frequent desiccation, or predation by terrestrial predators. It seems likely that there might be a corresponding depression in richness or density of some terrestrial organisms immediately uphill of the shoreline because of frequent inundation or disturbance.

Wrack deposition is an important disturbance on many shores. Heavy wrack kills vegetation (and presumably sessile or slow-moving animals), and can prevent a successional dominant from monopolizing the shore zone. Experimental work on marine shore zones shows that wrack deposition has strong effects on vegetational 
succession and composition, and favors fugitive species (Tolley and Christian 1999; Minchinton 2002).

Several common human activities change inputs of wave energy onto the shore zone. Breakwaters and other coastal defenses reduce inputs of physical energy. Less obviously, several common human activities (e.g., building the shore out into the water, dredging, seawall construction, boat wakes) increase energy inputs to the shore zone. The ecological effects of such changes probably are common and important.

\section{Biological interactions}

Although shore zones often are thought of as stressful habitats, leading to the possibility that biological communities are controlled primarily by stress rather than biological interactions, there is ample evidence that biological interactions structure shore zone communities. We will not document all of these interactions, but simply cite a few examples to show the strength and diversity of these interactions. Aquatic and terrestrial plants support animal communities that differ from those of unvegetated sediments, and often differ across plant species (e.g., Moon 1934; Brodersen 1995; Radomski and Goeman 2001; Romanuk and Levings 2003; Salovius and Kraufvelin 2004; Kraufvelin and Salovius 2004). Consequently, invasions of alien plants frequently not only push out native plants but also change associated animal communities (e.g., Ailstock et al. 2001; Strayer et al. 2003). Predation by terrestrial predators (birds and mammals) may be so intense that it reduces the density of aquatic prey near the water's edge by direct consumption or intimidation (Power 1984; Power et al. 1989; Burlakova and Karatayev 2007). Similarly, terrestrial predators may take large numbers of emerging aquatic insects (Paetzold and Tockner 2005), and aquatic predators affect the distribution, abundance, and behavior of their prey (Fig. 3). Interestingly, the emergence of aquatic insects may increase the populations of terrestrial predators in the shore zone enough to suppress populations of terrestrial herbivores (Henschel et al. 2001). Backlund (1945) reported extraordinarily high levels (86-100\%) of parasitism by wasps among wrack-dwelling dipterans. By absorbing wave energy, Spartina (cordgrass) moderates the environment enough to allow other plants to persist (Fig. 10; Kennedy and Bruno 2000). Thus, biological interactions in shore zones are varied, and often strong enough to affect the distribution and abundance of species, just as they are in other habitats.

\section{Inputs and stocks of organic matter}

Animal and microbial populations often are controlled by the amount and quality of organic matter (Cole et al. 1988;
McNaughton et al. 1991; Wallace et al. 1999). Considering the enormous range in organic inputs from open sandy beaches to wrack-covered shores, to wetlands covered by emergent plants to shores stacked with driftwood, it is reasonable to expect that the quantity and quality of organic matter controls the composition, abundance, and activity of many shore zone consumers. Densities of macroinvertebrates in the shore zone increase with organic content of the sediments (e.g., Brittain and Lillehammer 1978; McLachlan 1983; Dall et al. 1984), and experimental additions of wrack increase animal densities (Rossi and Underwood 2002). Likewise, tidying beaches by removing wrack reduces populations of terrestrial and aquatic consumers (Malm et al. 2004).

\section{Other physical and chemical controls}

A large number of other physical and chemical factors control the shore zone biota, but we will mention just a few of the most important: grain size, content of nutrients and organic matter, and redox status of the soil or sediment, and nutrient loading. Animal densities and community composition often vary with sediment grain size (e.g., Barton and Hynes 1978; McLachlan 1983; Dall et al. 1984; Rodrigues et al. 2006), although it may be difficult to disentangle the effects of grain size from those of sediment stability. Grain size affects substratum roughness, soil cohesion (and therefore its suitability for burrowing), and often is correlated with the content of organic matter. Grain size and organic content affect the ability of soils to hold water and nutrients, and should affect plant communities as well (Naiman et al. 2005).

The redox status of soils and sediments affects the shore zone biota in several ways. Soils and sediments with low redox potential (e.g., soils that are saturated, fine-grained, or have a high organic content) are poor habitat for most animals (e.g., McLachlan 1983) because dissolved oxygen is low or absent, and toxic substances such as sulfide and ammonia may be present. Although plant nutrients (ammonium, soluble reactive phosphorus) may be readily available in soils with low redox potential, the scarcity or absence of dissolved oxygen may stress or kill plants as well, unless they have special physiological adaptations for coping with these conditions (e.g., Sorrell et al. 2000).

Nutrient loading has strong direct and indirect effects on the shore zone biota. The direct effects of nitrogen or phosphorus loading are important to the shore zone vegetation. For instance, high loads of nitrogen from developed shore zones favor monocultures of Spartina (cordgrass) or Phragmites (common reed) in estuarine shore zones (Bertness et al. 2002; Chambers et al. 2008). High levels of phosphorus, whether from external loading or recycling by shore zone consumers, can favor the development of 
nuisance blooms of the macroalga Cladophora in fresh or slightly brackish water (Hecky et al. 2004; Kraufvelin et al. 2006). In addition to these direct effects, excessive nutrient loading can increase phytoplankton populations. Although phytoplankton is an important food for some shore zone animals (e.g., zebra mussels, net-spinning caddisflies), dense phytoplankton populations reduce water clarity, and therefore reduce the extent and productivity of submersed vegetation, with consequent effects on shore zone animals.

\section{Shore zones as habitat complexes}

Many animals use different parts of the shore zone during different parts of their life cycle, or move between the shore zone and nearby habitats. In this sense, the individual parts of the shore zone may function as parts of habitat complexes. There are many examples. Northern pike, yellow perch, and many other fish species use the shore zone as spawning or nursery areas, moving into the open waters of lakes or rivers as they mature. Some fish species use different parts of the shore zone during different juvenile stages (Scholten 2002). As a consequence, the overall composition of the shore zone, and connectivity among the parts of the shore zone and between the shore zone and other nearby habitats may be vital to maintaining biodiversity (Fig. 11; Amoros and Bornette 2002; Robinson et al. 2002).

\section{Energy dissipation}

Waves, currents, and wakes may focus enormous amounts of energy onto shore zones (Fig. 2), much of which can be dissipated by drag against the bottom, turbulence, suspension of sediments, or absorption. The amount of energy that is dissipated by the shore zone versus reflected back into the body of water varies greatly, depending on the slope,

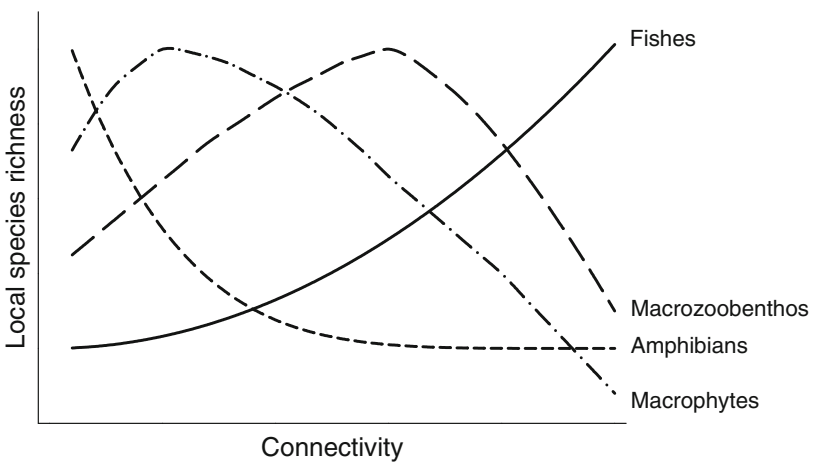

Fig. 11 Idealized relationships between species richness of aquatic biota and degree of hydrological connectivity of various bodies of water on a riverine floodplain ranging from the main channel of a river to remote floodplain pools (redrawn from Amoros and Bornette 2002, after Ward and Tockner 2001) roughness, and composition of the shore zone, including its biota. Shore zones with steep slopes often reflect more energy than flatter shore zones. Marine geomorphologists and ecologists make a fundamental distinction between typically steep, coarse-grained reflective beaches and typically flat, fine-grained dissipative beaches (Figs. 12, 13). Roughness, such as vegetation, bedforms, boulders, or engineered structures can be important in dissipating energy (Zhu and Chang 2001).

Shore zone vegetation may absorb significant amounts of wave energy, thereby reducing erosion along the shore (Fig. 14, Coops et al. 1996) and allowing other species to survive (Fig. 10; Kennedy and Bruno 2000). As a result of this reduction in physical energy, shore zone vegetation changes flow patterns, reduces near-bed shear stresses, and may cause local sediment deposition and change mesoscale geomorphology (e.g., bar formation) (Jordanova and James 2003; Baptist et al. 2005; Naiman et al. 2005). Roots of shoreline vegetation also can stabilize banks and provide a stable substratum for other species in the physically stressful shore zone (Gregory and Gurnell 1988; Sweeney 1993). If the protective shore zone vegetation is lost, whether from excessive energy inputs or other causes, it

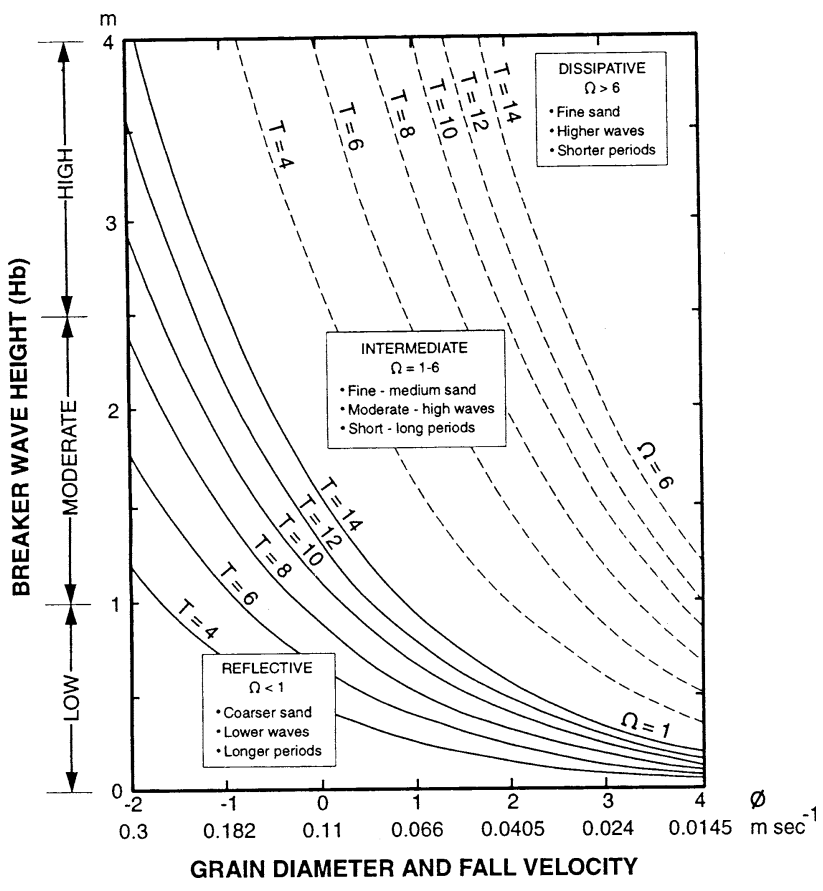

Fig. 12 Diagram to determine whether a beach is reflective, dissipative, or intermediate on the basis of breaker height $(\mathrm{m})$, wave period $(T$, in $\mathrm{s})$, and fall velocity $(\mathrm{m} / \mathrm{s})$ or grain diameter $(\varphi)$ of the beach particles (Short 1996). Reflective beaches (for which the dimensionless fall velocity $\Omega<1$ ) lie below the solid line for a given wave period, dissipative beaches $(\Omega>6)$ lie above the dashed lines for a given wave period, and intermediate beaches $(\Omega=1-6)$ lie between the two lines 


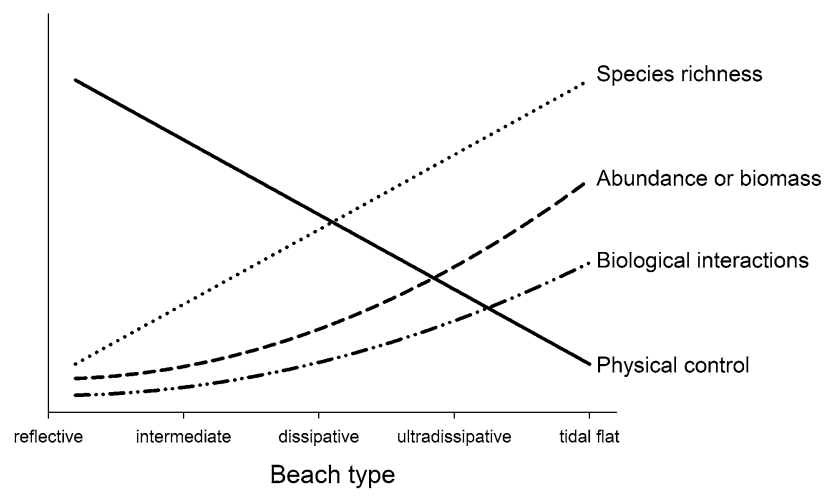

Fig. 13 Idealized relationships between beach geomorphology, ecological processes, and aquatic macroinvertebrates along sandy beaches (modified from Defeo and McLachlan 2005). Beach types are arranged from highly reflective to highly dissipative

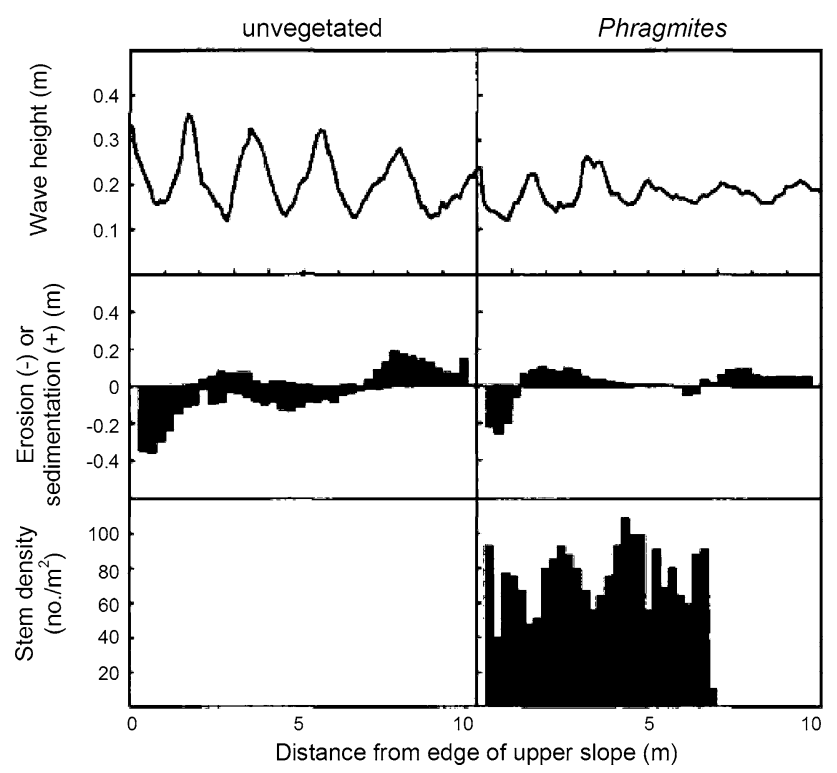

Fig. 14 Effects of Phragmites australis on wave attenuation and bank erosion in an experimental wave tank (Coops et al. 1996). Waves approach from the right

may be necessary to construct artificial barriers, which often are expensive and ineffective (Johnson 2002).

In other cases, shore zone vegetation may focus water flow to increase shear stress and erosion (Widdows et al. 2008). The amount of energy that is absorbed or focused by the vegetation, along with the consequent erosion or deposition, will depend on the details of the structure of the vegetation and the local flow environment.

Accumulation and processing of organic matter

The shore zone accumulates and processes large amounts of organic matter. Some of this organic matter originates from on-site primary production in the shore zone, which can be among the highest recorded from any habitat (Wetzel 1990). Of course, on-site primary production in other shore zones (highly exposed rocky or sandy shores, or many engineered shore zones) may be negligibly small.

In addition to this on-site primary production, large amounts of organic matter can be washed into and retained by shore zones from adjacent ecosystems. This matter can be focused onto narrow bands ("wrack") along the shore, and so reach enormous densities. Deposition, decomposition, and animal communities of wrack have been well studied by marine ecologists, who have recorded deposition rates as high as $2,920 \mathrm{~kg}$ wet mass per meter of shoreline per year (Backlund 1945; McLachlan 1983; Polis and Hurd 1996; Colombini and Chelazzi 2003; Orr et al. 2005). Typically, marine wrack is dominated by kelp and other macroalgae, but it may be dominated by vascular plants (e.g., eelgrass, Spartina) or wood at sites near major rivers. Inputs of animal carrion may also be significant (>100 g dry mass/m-year; Colombini and Chelazzi 2003). Wrack seems not to have been much studied in fresh water, although it may be an important source to freshwater shore zones as well. Wrack accumulations as high as $\sim 5 \mathrm{~kg}$ dry mass $/ \mathrm{m}^{2}$ (chiefly Vallisneria americana or wood) are common along the shores of the freshwater tidal Hudson River, which is 60-fold higher than plant biomass in living Vallisneria beds (Strayer et al. unpublished). Much greater accumulations surely exist along freshwater shores. The amount of wrack that is deposited and retained on a shore depends on the amount of organic matter that is generated locally, the hydrologic regime, and the slope and roughness of the shore (Fig. 15; Backlund 1945; Orr et al. 2005).

Wrack is an important source of organic matter to shore zones, especially where on-site primary production is small (e.g., sand beaches), and may be an important source of soil organic matter (McLachlan 1983, 1985; Rossi and Underwood 2002). Although some of this organic matter is exported from the shore zone (wrack accumulations in particular can be very ephemeral-Backlund 1945; Orr et al. 2005), much of it is decomposed on site, supporting very high rates of respiration and production by microbes and animals (McLachlan 1985; Polis and Hurd 1996; Jedrezejczak 2002a, b; Coupland et al. 2007). Initially, large amounts of dissolved organic matter are leached from the wrack (Jedrezejczak 2002a), which can be an important source of dissolved organic matter to the shore zone soils (Malm et al. 2004) and nearshore waters. Marine wrack is rapidly colonized by both microbes and invertebrates (Backlund 1945; Jedrezejczak 2002b), which together decompose the organic matter. Animals often prefer to feed on aged wrack (Backlund 1945; Pennings et al. 2000), probably because it contains higher microbial biomass and lower concentrations of defensive chemicals than fresh wrack. The nitrogen and phosphorus released in the 

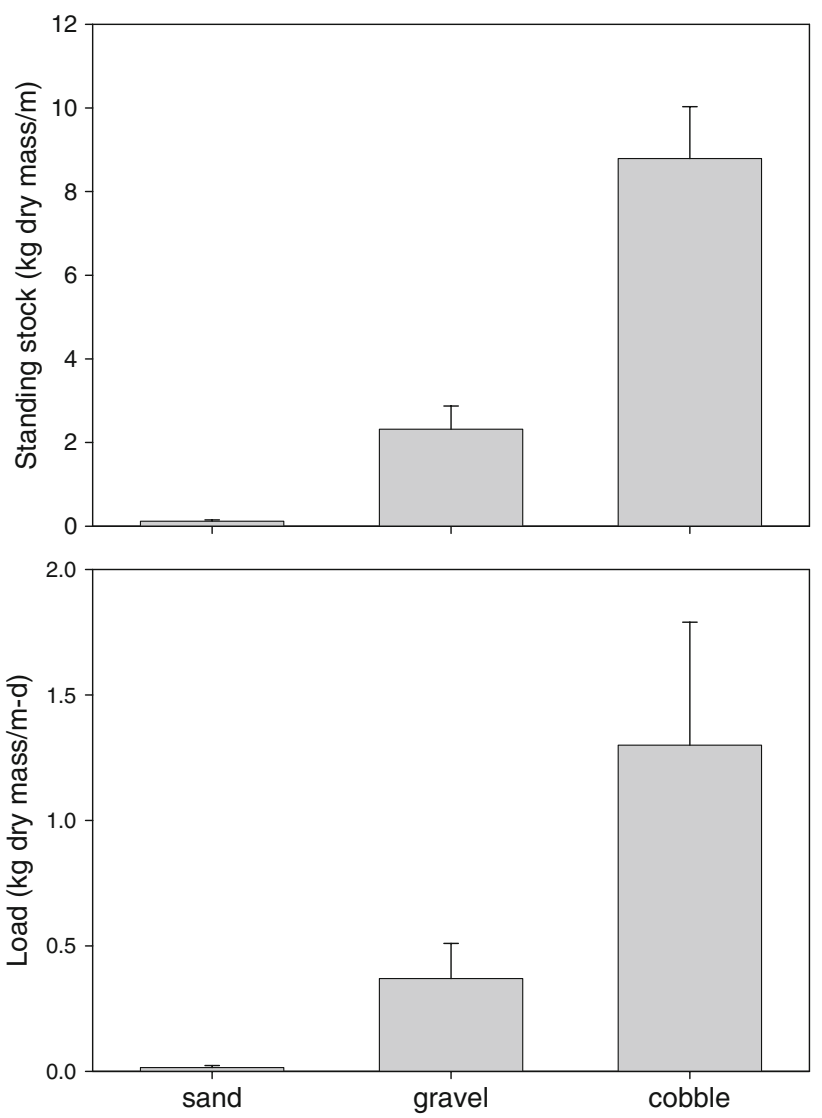

Fig. 15 Standing crop (upper) and daily input (lower) of wrack on beaches of different grain sizes in British Columbia. Data are medians + median absolute deviation ( $n=3$ samples), from Orr et al. (2005)

mineralization of wrack can be an important source of nutrients to nearshore microbes and phytoplankton (Malm et al. 2004), as well as terrestrial microbes and vegetation.

By virtue of its complex physical structure and high food availability, marine wrack supports large populations of invertebrates, typically dominated by dipterans, enchytraeid oligochaetes, collembolans, mites, and amphipods (e.g., Backlund 1945; Behbehani and Croker 1982; McLachlan 1983, 1985; Marsden 1991; Jedrezejczak 2002a, b; Romanuk and Levings 2003; Garbary et al. 2004). Most of these species are detritivores or bacteriovores, and many are good colonizers, and so are able to take advantage of ephemeral wrack accumulations. Large populations of predators, both invertebrate (e.g., carabid beetles, spiders-Backlund 1945; Paetzold et al. 2008a, b) and vertebrate (e.g., shorebirds-Elias et al. 2000; Dugan et al. 2003) feed on these primary consumers.

Apart from its importance in shore zone food webs, the physical structure of wrack may affect shore zone geomorphology, biogeochemistry, and biodiversity (Backlund 1945; Pieczyńska 1972). Temperature and moisture are moderated within and beneath a wrack bed (Backlund
1945; Coupland et al. 2007), and dense wrack may impede oxygen diffusion, leading to hypoxia or anoxia. This leads to steep vertical gradients in environmental conditions, biodiversity, and biogeochemical processes within a wrack bed (e.g., Backlund 1945). Some birds nest in and around wrack (Smith and Renken 1991; Maccarone et al. 1993). Floating wrack may be an important means of dispersal for shore zone organisms (Backlund 1945; Salovius et al. 2005; Minchinton 2006).

Humans often remove wrack from the shore zone, formerly as a resource to fertilize fields, thatch roofs, and build fences (Backlund 1945), and now to tidy beaches (e.g., Dugan et al. 2003). In addition to any effects resulting from sediment compaction from machines used to remove wrack, wrack removal can reduce organic matter in shoreline soils and sediments (Dugan et al. 2003; Malm et al. 2004), reduce nutrient concentrations offshore (Malm et al. 2004), and reduce microbial and animal numbers, biomass, or production in the terrestrial and aquatic parts of the shore zone (Dugan et al. 2003; Malm et al. 2004). Other human modifications of the shore zone (destruction of seagrass beds, replacement of gently sloping shores with vertical seawalls, removal of shore zone vegetation and other roughness elements) probably have greatly reduced wrack accumulation on many shores, with large ecological consequences.

The combination of saturated soils and high organic matter makes shore zones ideal habitats for anaerobic processes such as denitrification, sulfate reduction, and methanogenesis. Ecologists have reported high rates of these processes in shore zones, especially in plant beds or wrack accumulations where labile organic matter is abundant (e.g., Juutinen et al. 2003; Kankaala et al. 2004; Hirota et al. 2007). Notably, many of the products of anaerobic metabolism, including methane, sulfide, hydrogen, and ferrous iron, can themselves be used as a source of energy by microbes with access to oxygen. Because aerobic and anaerobic microhabitats are closely juxtaposed in most shore zones, there is often close coupling between aerobic and anaerobic processes. This coupling can lead to high rates of biological activity and rapid decomposition of organic matter.

\section{Wood in the shore zone}

Woody debris often accumulates in freshwater shore zones. Although it is not usually an important source of energy to the shore zone biota (but see Hoffmann and Hering 2000; Benke and Wallace 2003; Wondzell and Bisson 2003 for examples of wood-eating insects), this dead wood plays several important ecological roles. Some of this wood originates locally, from riparian trees that fall into the water and decay in place. Because of bank instability and 
exposure to high winds, inputs of wood from shore zone forests presumably are much greater than in most upland forests. However, in large lakes and rivers, currents and waves may transport wood considerable distances. The amount of wood along shorelines varies over wide ranges (Gurnell 2003; Marburg et al. 2006). Wood tends to accumulate in characteristic locations-on the upstream end of islands and bars, in strands parallel to and above the water line (especially on low-slope shores), at the mouths of side channels, or around retentive structures such as standing tree trunks and bridge abutments (Gurnell 2003).

Woody debris structures the morphology of the shore zone, at micro- to mesoscales (Gurnell et al. 2005). Woody debris encourages island formation, armors shores where large accumulations occur, and tends to increase mesoscale spatial heterogeneity (Piégay 2003; Gurnell et al. 2005). Wood accumulations retain smaller particles of organic matter (Wondzell and Bisson 2003), and may therefore be sites of high food availability for detritivores and decomposers. At small scales, flow patterns around pieces of wood produce local variations in topography (including small pools), sediment grain size, and organic content. All of this wood-induced heterogeneity provides a rich array of meso- and microhabitats for the shore zone biota, and must have large effects on species composition and richness.

Woody debris has other strong effects on the shore zone biota. Where the primary substratum is unstable (e.g., sand in high-energy environments), wood snags offer stable substrata, and may support very high densities of invertebrates (Benke and Wallace 2003; Wondzell and Bisson 2003). Wood also simply increases surface area available for bacterial and algal biofilms, as well as invertebrates. Coarse woody debris shelters fishes from predators; provides visual isolation from competitors, allowing higher local densities of competitors; provides food and foraging sites; offers shelter for nests and young; and provides visual landmarks for homing or site recognition (Vogele and Rainwater 1975; Crook and Robertson 1999; Benke and Wallace 2003; Zalewski et al. 2003). Some species spawn around woody debris (e.g., Vogele and Rainwater 1975; Cochran and Cochran 2005). Experimental addition of woody debris decreased predation rates on grass shrimp in a Maryland estuary (Everett and Ruiz 1993), and high densities of woody debris may enhance growth rates of fish (Fig. 3; Schindler et al. 2000). Aquatic insects use terrestrial wood for emergence, oviposition, and resting sites (Benke and Wallace 2003), and terrestrial vertebrates use wood accumulations as sites for perching and basking and shelter for nests and dens (Steel et al. 2003). Consequently, densities of animals often respond to increases or decreases in availability of woody debris (Fig. 3; Everett and Ruiz 1993; Scholten et al. 2005; Sass et al. 2006). Like other physical structure in the shore zone, the importance of wood varies with the availability of other structure; wood usually has the greatest ecological effect in shore zones where other structure is lacking (Crook and Robertson 1999; Benke and Wallace 2003). Finally, floating wood can raft species from place to place in the shore zone (Gurnell et al. 2005; Thiel and Gutow 2005), and thus contribute to dispersal and connectivity across shore zone populations.

There has been relatively little work comparing the ecological value of woody debris from different species of trees. Fresh debris from some tree species (poplars and willows) can reroot after it is transported, so such debris is more stable and less subject to subsequent transport than debris from other species (Gurnell et al. 2005). Bark roughness, wood hardness, and the age of the wood may affect aquatic invertebrates (Bowen et al. 1998; Magoulick 1998), and the size of the hiding spots in wood accumulations affects the species and sizes of fishes that use these accumulations (Bolding et al. 2004).

Several human activities have greatly reduced the amount of shore zone wood, so that modern shore zones contain substantially less wood than natural shore zones. Humans remove wood from river channels to improve recreational and commercial navigation (Angradi et al. 2004), to tidy the appearance of shoreline properties (Christensen et al. 1996; Francis and Schindler 2006), or to reduce the likelihood of damage to infrastructure. Humans have cut many riparian forests, removing the source of wood to the shore zone (Christensen et al. 1996; Angradi et al. 2004; Francis and Schindler 2006; Scholten et al. 2005). Reservoirs act as traps for wood (Piégay 2003), and stabilized river flows tend to reduce bank-cutting, which is an important source of wood to rivers, as well as reducing the ability of the river to transport wood (Angradi et al. 2004). Humans also remove much of the roughness from shore zones, decreasing their ability to retain floating wood (Piégay 2003). All of these activities have greatly reduced stocks of woody debris, especially in large rivers (Figs. 3, 16). These large losses may have important consequences for the functioning of shore zone ecosystems.

Other kinds of organic matter may accumulate in the shore zone as well. Just as wave energy focuses wrack into small areas, insect emergence can funnel animal biomass into the shore zone. These inputs can be considerable in large lakes and rivers, and support large populations of terrestrial predators in the shore zone, including carabid beetles, spiders, insectivorous birds, and bats (Backlund 1945; McLachlan 1983; Gray 1993; Paetzold and Tockner 2005; Paetzold et al. 2005; Smith et al. 2004, 2007). This enhancement of predator populations in the shore zone may be large enough to suppress populations of terrestrial prey as well (Henschel et al. 2001). Animals that spawn in the shore zone (e.g., yellow perch, sunfishes) may also focus large amounts of very labile organic matter into the shore 


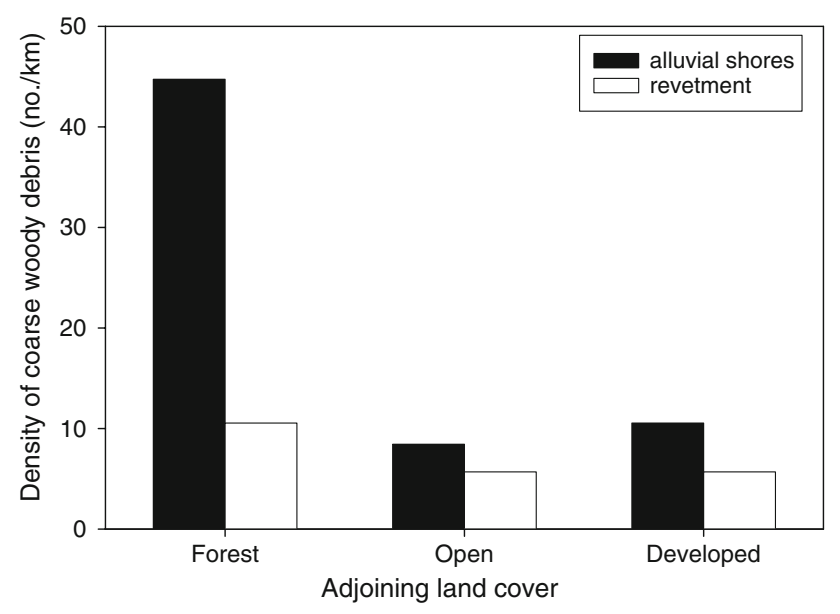

Fig. 16 Density of coarse woody debris (pieces $>5 \mathrm{~m}$ long and $>0.3 \mathrm{~m}$ in diameter) along the shores of the upper Missouri River, as a function of bank type and adjoining land cover (modified from Angradi et al. 2004). The natural condition of most of this shore zone would have been alluvial and forested (the bar on the far left)

zone. In addition floatable organic pollutants (plastics, oils) often accumulate in shores zones; their effects will be addressed briefly under "Human impacts on the shore zone" (below).

\section{Processing of nutrients}

Shore zones frequently support high rates of nutrient cycling (McClain et al. 2003). Shore zones intercept nutrients that are moving from the land into the water, capture nutrients from the water, and liberate nutrients in the process of decomposition of organic matter. The first of these has received the most attention because of the interest in using riparian zone buffers to reduce nutrient loading (especially nitrogen) to surface waters (e.g., Lowrance 1998). The plants and microbes of the shore zone can be very effective in capturing incoming nitrate and ammonium and converting it into biomass, detrital organic nitrogen, or $\mathrm{N}_{2}$ gas (via denitrification). Likewise, phosphorus can be retained by shore zone plants, microbes, or soils. Although much attention has been focused on terrestrial plants, aquatic plants and microbes also can retain nutrients (Wetzel 1990). These valuable functions can be disrupted if the shore zone vegetation is removed or if patterns of water flow through the shore zone are changed (e.g., by construction of impermeable barriers such as seawalls or other coastal defenses, or by changing water levels-Groffman et al. 2003). Humans commonly make such changes to shore zones, and probably have compromised the abilities of many shore zones to trap nutrients.

Nutrients from the water likewise may be taken up and incorporated into organic matter or denitrified by shore zone plants and microbes. Marine ecologists have emphasized the importance of wave-driven water movement through permeable sediments in boosting uptake of nutrients and organic matter by interstitial microbes (McLachlan 1983). Some of these water-derived nutrients may be moved uphill into terrestrial ecosystems by insect emergence, uptake by terrestrial plants, or consumption of aquatic prey by terrestrial predators.

As was discussed earlier, nitrogen and phosphorus are liberated as organic matter is decomposed. Because the amount of organic matter that is decomposed in the shore zone may be very large, either from on-site primary production or wrack deposition, correspondingly large amounts of inorganic nitrogen and phosphorus may be released. These nutrients may be exported to nearshore waters (e.g., Malm et al. 2004) or taken up by the shore zone biota (Addy et al. 2005).

\section{Corridors}

For reasons already noted, shore zones can be important corridors for the movement of both plants and animals, knitting together different populations of a species into a functional metapopulation, or allowing animals to exploit different regions in different seasons. Thus, many migrating birds follow shorelines, and shore zone plants can be dispersed along the shore by floating (Jansson et al. 2005) or ice-rafting (Hill et al. 1998). Fish likewise may disperse along the shore zone rather than in the open water (Reichard et al. 2004).

The value of different shore zones as corridors must vary widely, depending on their length, orientation, availability of cover, and water movement. Long, nearly linear shore zones such as those along major rivers must be much more important as dispersal corridors than the small, closed shore zones around small isolated lakes. The orientation of the shore zone relative to the direction of animal migration must also affect the extent to which it is used as a dispersal corridor, although not always in a straightforward fashion-a shore can be used heavily because it is along the direction of movement (the northsouth Mississippi River for migrating birds) or because it lies across the direction of movement (the east-west shores of Lake Erie for migrating birds). The presence of nearshore currents must greatly increase the value of shore zones as dispersal corridors by providing a mechanism for passive dispersal of the biota (Hill et al. 1998; Nilsson and Svedmark 2002; Jansson et al. 2005). The availability of logs, wrack, ice, and plastic may affect dispersal as well, because these floatable platforms may be important in dispersing terrestrial organisms (Hill et al. 1998; Gurnell et al. 2005; Salovius et al. 2005; Thiel and Gutow 2005). 
Human activities have greatly changed the value of many shore zones as dispersal corridors. Dams and habitat destruction fragment freshwater shore zones, and presumably greatly reduce their value as dispersal corridors. Reservoirs in particular can act as traps for biota dispersing along river corridors (Jansson et al. 2005). On the other hand, marine ecologists have suggested that coastal defense structures such as groynes and breakwaters serve as stepping stones and enhanced dispersal of organisms that use the hard surfaces and quiet backwaters created by these structures (Thompson et al. 2002; Airoldi et al. 2005; Bulleri and Airoldi 2005). Presumably these same effects occur along large lakes and rivers that have been protected by similar structures.

\section{What sets the character and functioning of the shore zone?}

It should be apparent that from this brief review that many factors control the structure and function of freshwater shore zone ecosystems. Nevertheless, by analogy with Jenny's (1941) analysis of state factors for soil development, we can think of the ecological character and function of shore zones as being determined chiefly by six interdependent classes of factors (cf. Meadows et al. 2005): inputs of physical energy to the shore zone; the geological or engineered structure of the shore zone and its environs; the hydrology of the shore zone; inputs of nutrients; the biota of the shore zone; and the climate to which the shore zone is exposed. We are not suggesting that these factors completely determine the character of every freshwater shore zone, but taken together they capture most of the variation in freshwater shore zones. We discuss each of these six factors briefly below.

\section{Physical energy regime}

One might be tempted to see the physical energy regime as the master variable that controls the ecological character of the shore zone. In this view, given enough time, the materials and morphology of the shore zone would adjust to the energy regime. Materials fine-grained or light enough to be suspended by the ambient energy regime would be swept away, while materials too large or heavy ever to be moved would be covered by mobile particles. Thus, low-energy beaches would be dominated by finegrained sediments, and high-energy beaches by coarsegrained sediments. Bedforms (e.g., ripples) and shore zone slopes also would adjust to match the energy regime, so the physical structure of the shore zone would depend only on the energy regime. One might also view the biota as ultimately dependent on energy inputs. This view is analogous to the idea of the graded alluvial river that has been widely discussed in stream geomorphology and ecology (e.g., Leopold et al. 1964).

Real shore zones are so far from this ideal world that the idea of equilibrium with the energy regime would seem to have little use, except perhaps as an ideal standard against which real shore zones can be compared. Even in open marine beaches, perhaps the case that most closely approaches the ideal, the idea of an equilibrial beach profile has been sharply criticized (Pilkey et al. 1993). Many natural shore zones other than sandy beaches contain materials that are far too coarse to be transported by the ambient energy regime (e.g., boulders or bedrock), have an insufficient supply of fine materials that could be deposited or sculpted by the ambient energy regime, or have energy inputs that are so variable over time that the shore zone structures never "catch up" to reach equilibrium with the instantaneous energy regime. Deviations from the ideal world are even more pronounced along human-dominated shore zones, where humans often introduce materials or structures that are deliberately designed to be immobile under the ambient energy regime (seawalls, riprap), or alter the energy regime (dredging, filling, breakwaters, etc.). The physical structure of these human-dominated shore zones often is far out of equilibrium with the energy regime. Thus, it seems impossible to treat the character of the shore zone as depending solely on the energy regime, and it will be necessary to include the physical structure of the shore zone as a separate controlling factor.

Nevertheless, even if the energy regime is not the master variable that sets the character of shore zone ecosystems, it surely must be considered as $a$ master variable. The energy regime does have strong effects on the physical structure of the shore zone (particle sizes, bedforms, slope), even if it does not completely determine it. Physical structure in turn has strong and pervasive effects on biodiversity and biogeochemistry, through its effects on factors like the disturbance regime, retention of wrack and woody debris, etc. The energy regime also affects turbulent mixing in nearshore waters and sediments, as well as pumping of water through nearshore sediments by wave action, with consequent effects on biogeochemical processes. The energy regime also directly affects the behavior, movement, passive dispersal, and morphological structure (e.g., Puijalon et al. 2008) of the shore zone biota. Consequently, there are very pronounced differences in ecological structure and function between low- and high-energy shore 
zones (cf. Figs. 12, 13). Many of the most important human effects on shore zone ecosystems are a result of changes to the energy regime.

\section{Structure}

"Structure" includes a wide range of attributes of the shore zone that affect ecological functioning, including the grain size of the soil or sediment, the types of materials that constitute the soil or sediment, the surface topography or roughness of the shore zone at various scales, the slope of the shore zone, and the plan view shape of the shoreline. Grain size affects the permeability (and therefore water movement and redox potential), water-holding capacity, internal surface area (and therefore exchange capacity), cohesion, and stability of soils and sediments, and so has large, pervasive effects on biological distributions and biogeochemical processes. Given the same grain size distribution, different materials produce different ecological effects. For instance, materials with different specific gravities differ in their mobility and susceptibility to disturbance, and materials of different chemical composition will differ in their fertility to support plant growth. Of course, different materials weather differently as well, so that they produce different grain size distributions even when exposed to the same environmental settings. Surface topography determines the availability of micro- and mesohabitats in the shore zone, some of which (e.g., crevices, supralittoral pools) are hot spots for biodiversity and biogeochemical processing (e.g., Pieczyńska 1972; Chapman and Bulleri 2003; Le Hir and Hily 2005). A high diversity of micro- and mesohabitats encourages high biodiversity (Figs. 3, 4) and close coupling of biogeochemical cycling (such as nitrification-denitrification in adjacent oxic and anoxic microhabitats). Topographic roughness also increases retention of organic matter and other materials (Fig. 15). The slope of the shore zone affects its ability to dissipate or reflect wave energy (Fig. 12) (and therefore the frequency and intensity of disturbance), the area of the shore zone (Fig. 8), the ability of the shore zone to retain wrack and wood, and the relationship between fluctuations in water level and area inundated. The plan view of the shoreline has effects that are analogous to topographic roughness, and also determines the provision of micro- and mesohabitats and the retention of organic matter and other materials. Consequently, the structure of the shore zone has large effects on its ecological functioning. Human activities such as dredging, channelization, filling, grading, and shoreline armoring have had large effects on shore zone structure, and therefore shore zone ecology.
Hydrologic regime

By "hydrologic regime", we mean the temporal pattern of water-level fluctuations along a shoreline. Shoreline hydrology could be described in several ways. Perhaps the simplest would be a plot of water levels over time (Fig. 17). More useful in comparing two or more shorelines, or in assessing the effect of human-induced changes to hydrology, would be a plot giving the amplitude of water-level fluctuations at various frequencies (waves, tides, daily changes, seasonal changes, etc.). Frequencyamplitude plots like those of Sabo and Post (2008) could be applied to shore zone water level data to allow for easy comparison across sites or time (Fig. 17). However, even this detailed plot lacks important information about the hydrologic regime; in particular, the timing of water-level fluctuations. Thus, for some applications, it will be useful to take into account fluctuations at certain, critical times of the year, or to look specifically for shifts in timing of key events. The literature on hydrologic alteration in stream flows (Richter et al. 1996; Olden and Poff 2003) may be a useful model for more detailed analyses of shoreline hydrology.

Hydrology has large and pervasive effects on the functioning of shore zone ecosystems (Wantzen et al. 2008). Obviously, the water level determines the precise location of the shoreline, with everything that implies for energy dissipation, sediment dynamics, biogeochemical processes, and the location and quality of various microhabitats along the shore. Bodies of water in which the water level has been artificially stabilized can lose the rich array of ephemeral habitats along their margins (Robinson et al. 2002). These habitats often are sites of high biogeochemical processing (Fig. 18; Pieczyńska 1972) and biodiversity.

Gradual long-term rises in water level frequently lead to erosion along the shoreline, whereas long-term falls in water level often lead to sediment deposition in the shore zone (e.g., Lorang et al. 1993; Lavalle and Lakhan 2000). Raising or lowering water levels quickly may greatly increase erosion, as soils and sediments that were not previously exposed to currents, wave action, and ice are now subjected to increased physical forces (e.g., Lorang et al. 1993). This erosion may be exacerbated if the new hydrologic regime discourages colonization by vegetation (Walker et al. 1994), which can stabilize soils and sediments, as in the case in flood-control or hydropower reservoirs.

The hydrologic regime also strongly influences biogeochemical processes in the shore zone. Most importantly, oxygen diffusion is orders of magnitude slower in water than in unsaturated soils, and leaching is 

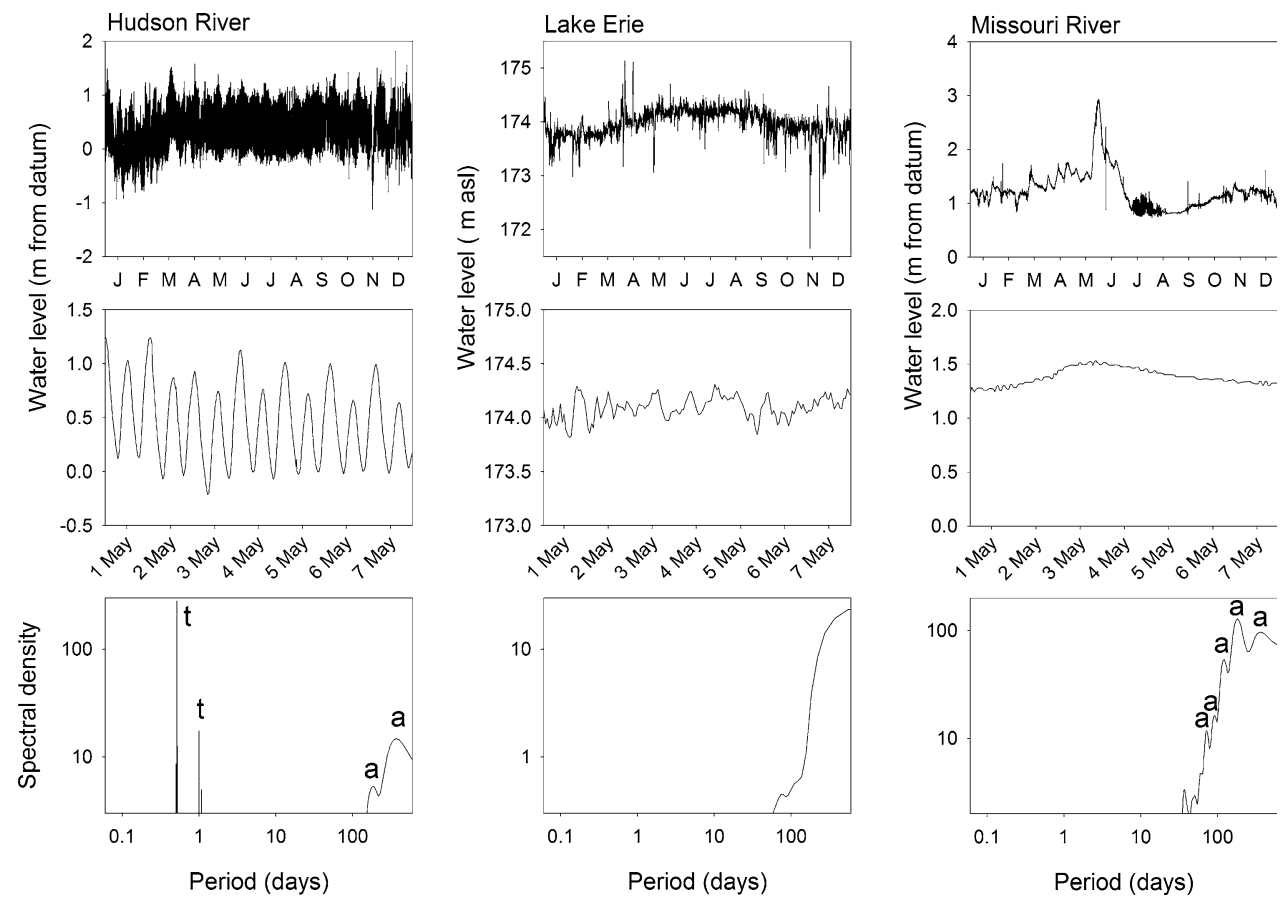

Fig. 17 The water-level regime along three shorelines: the freshwater tidal Hudson River near Poughkeepsie, NY; Lake Erie at Toledo, $\mathrm{OH}$; and the Missouri River at Toston, MT. The upper panels show an entire year (calendar year 2003) the middle panels show finer-scale variation (the first week in May), and the lower panels show a spectral analysis of the long-term record (5-10 years). The hydrologic regime along the Hudson is dominated by great variation at short time-scales (a result of twice-daily tides, peaks " $t$ " on the spectral analysis) and smaller annual cycle (peaks " $a$ " on the spectral analysis); that of Lake
Erie shows limited variation at longer time-scales, and occasional extreme water levels, presumably resulting from wind-driven seiches; and that of the Missouri River is dominated by annual spring snowmelt (peaks " $a$ " on the spectral analysis, showing the annual peak as well as related peaks at $365 / n$ days), with occasional stormflows through the rest of the year. Data were taken every $15 \mathrm{~min}$ (Hudson, Missouri) or $60 \mathrm{~min}$ (Erie), and therefore do not show shortterm variation in water levels from wind-driven waves and boat wakes. Data from NOAA (2008) and USGS (2009a, b)

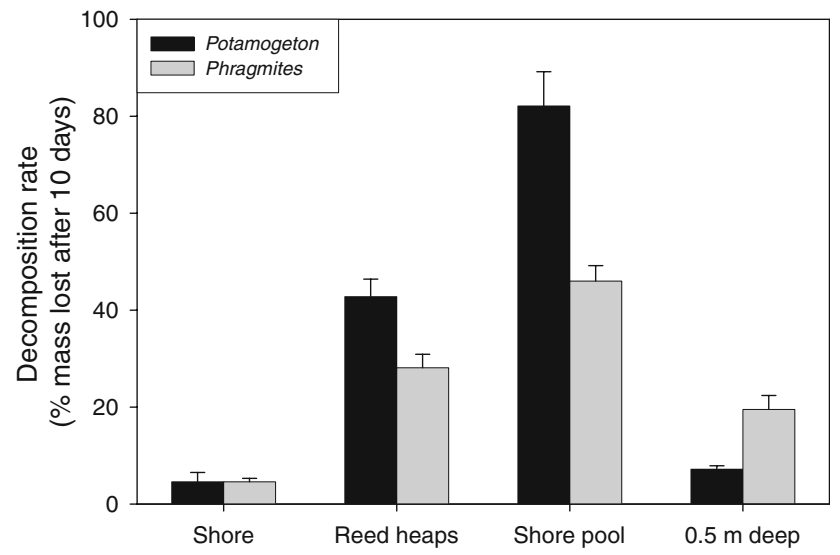

Fig. 18 Decomposition rate of two kinds of plant litter at various sites along a Polish lakeshore; the elevational gradient runs from high ground on the left to deeper water on the right (from data of Pieczyńska 1972)

much higher in the water than in soils. Consequently, reducing conditions are likely to occur in underwater sediments or saturated soils, leading to increased availability of soluble phosphorus, a predominance of ammonium over nitrate, and increased concentrations of the reduced form of metals such as ferrous iron and manganous manganese, and anaerobic metabolism. The alternation or close physical juxtaposition of oxidizing and reducing conditions can lead to coupling of aerobic and anaerobic biogeochemical processes, and rapid and efficient biogeochemical cycling (Baldwin and Mitchell 2000). Leaching is partly responsible for the more rapid disappearance of organic matter underwater than on nearby terrestrial soils (Langhans and Tockner 2006), and may be an important source of DOC to rivers and lakes. Thoms (2003) suggested that cutting linkages between a regulated river and its floodplain could reduce DOC inputs to the river. The alternation of wet and dry periods along the shore zone can speed the decay of organic matter, especially in standing waters where the supply of oxygen to underwater sediments may limit decomposition (Battle and Golladay 2001; Langhans and Tockner 2006). Indeed, it has been suggested that the "moving littoral" of rivers with large, predictable water-level fluctuations is responsible for the high biodiversity and productivity of these ecosystems (Junk et al. 1989; Bayley 1995; Hamilton et al. 1995). 
The hydrologic regime is therefore one of the most important determinants of the ecological character of the shore zone. Humans have altered the hydrologic regimes of many shore zones, either by increasing fluctuations in water levels (flood-control or hydropower reservoirs), stabilizing water levels (lakes used for recreation), or changing the timing of water-level fluctuations (Walker et al. 1994; Hill et al. 1998; Wantzen et al. 2008). These human-induced changes can have large ecological effects on nearly all aspects of the shore zone ecosystem, and so are regarded as one of the largest current threats to the shore zone and its inhabitants (e.g., Schmieder 2004; Winfield 2004).

\section{Nutrients}

Nutrients often control the quantity and quality of biological production in the shore zone. In natural shore zones, nutrient inputs are controlled largely by the geological structure of the shore zone and its surroundings, but modern shore zones often are dominated by human inputs from sewage, urban and agricultural runoff, and atmospheric deposition. Even small changes in the inputs of phosphorus and nitrogen can affect the species composition and productivity of macrophytes and algae (e.g., Bertness et al. 2002; Hecky et al. 2004; Boers and Zedler 2008; Rosenberger et al. 2008).

\section{Biota}

Although the biota often is considered to be a variable that depends on the character of the shore zone, it also helps to determine the character of the shore zone, and is not completely dependent on other variables. The biota provides structural roughness that dissipates energy and retains organic matter, stabilizes sediments against erosion, provides materials (woody debris, wrack, shells) that structure the shore zone, produces and decomposes organic matter, carries oxygen into anoxic sediments and reduced substances into the oxic zone (e.g., Dacey 1981; Wigand et al. 1997; Wang et al. 2001), and cycles nutrients. Biota-biota interactions are among the most important determinants of biodiversity. Thus, the composition of the biota has broad and deep effects on the character of shore zone ecosystems and the ecological services that they provide (Jenkins et al. 2008).

Because of dispersal limitations, shore zones that are geographically distant from one another typically support different biotas, even if local environmental conditions are similar. As a result, it is impossible to precisely predict the shore zone biota solely from local environmental conditions.
The importance of these dispersal limitations and the role of the biota in the functioning of shore zone ecosystems is demonstrated by the large number of alien species that humans have introduced into shore zones and the large ecological changes that have followed these invasions. If biogeographic barriers were unimportant, species would have already occurred in all suitable sites, and human activities would be unable to expand their ranges; this is clearly not the case. Likewise, if the biota were unimportant to shore zone functioning, then species invasions would not cause any changes in ecological functions or services. As will be discussed below, this also is untrue. For all of these reasons, it seems necessary to include the biota as one of the master variables that determines the character of shore zone ecosystems.

\section{Climate}

Climate exerts its influence on shore zone ecosystems in large part by acting through one of the other four controlling factors, and so it might not be necessary to include it as a separate controlling factor. For instance, climate has a strong influence on the hydrologic regime and the biota of the shore zone, so climatic effects are partly accounted for when we consider hydrologic regime and biota. Nevertheless, some climatic influences on shore zone ecosystems are not expressed through hydrology or the biota. Ice rafting and ice-push affect shore zone morphology, transport sediment (Dionne 1993), and disturb the biota (e.g., Begin and Payette 1991); the occurrence and severity of these effects depends on climate. Likewise, climate sets the length of the growing season and metabolic rates, and so can affect the functioning of shore zones independent of the composition of the biota. Climate will affect the rate at which coarse woody debris enters the shore zone via windthrow. As a result, although climate works partly through hydrology and the biota, its influence is not expressed entirely through these other factors, and it seems useful to retain it as an independent factor determining the character of shore zone ecosystems. Human-induced climate change probably did not have large effects on shore zone ecosystems in the past, but is likely to be an important factor in the next few decades, particularly as it stimulates new human modifications of shore zones.

\section{Human impacts on the shore zone}

Human activities have profoundly affected shore zone ecosystems and threaten the ability of these ecosystems to provide valued ecological services (Brown and McLachlan 2002; Thompson et al. 2002; Tockner and Stanford 2002; 
Ostendorp et al. 2004; Airoldi and Beck 2007). We briefly review the most important of these impacts.

Compression and stabilization of the shore zone

Despite the many ecological services that they provide, shore zones often have been seen as waste lands, to be improved or replaced. Consequently, humans have dredged shallow waters to make them useful for navigation, and filled terrestrial parts of the shore zone, built levees, and regulated river flows to keep flood waters away from the landward portion of the shore zone. These activities have stabilized the location of the shoreline and reduced the width or area of the shore zone. These effects can be very large (Fig. 20; Hein et al. 2005; Miller et al. 2006); Tockner and Stanford (2002) reported that the ratio of the area inundated during high water to the area inundated at low water fell from 16.8 to 4.9 following human-induced modifications to the Mississippi River. Although the overall ecological consequences of the compression and stabilization of the shore zone have not been estimated, they must be very large. Compression of the shore zone of course reduces its area, but also probably reduces some of the habitats and the heterogeneity of the shore zone, both of which should have large effects on biodiversity and biogeochemical processes.

Fixing the location of the shoreline can also lead to the problem of "coastal squeeze", in which the shore zone narrows further if water levels change in the future. This effect has been recognized chiefly as a threat to marine shore zones, which will be narrowed or eliminated as shore zones are squeezed between a rising sea and fixed coastal defenses (such as levees) (Airoldi and Beck 2007; Winn et al. 2005; Fujii and Raffaelli 2008). Substantial coastal squeeze has already occurred along some marine shores as a result of rising sea levels (National Research Council 2007). An analogous squeeze can occur in fresh waters as a result of either rising (squeeze between a landward levee and an advancing shoreline) or falling (squeeze between a dredged navigation channel and a receding shoreline) water levels. The more we try to narrow the shore zone and fix the location of the shoreline, the more likely that coastal squeeze will threaten shore zone ecosystems.

Changes to the hydrological regime

Humans have changed the hydrologic regime of many freshwater shore zones through water diversions, dams that regulate water flow (e.g., for flood-control or peaking hydropower), or water-control structures (low outlet dams on many lakes). Because of the importance of hydrologic regime as a master variable that controls many aspects of shore-zone ecosystem functioning (Fig. 5), these changes in hydrologic regime have led to large changes in shore zone ecology. The effects of changing hydrologic regime on the ecology of freshwater shore zones probably will increase in the twenty-first century as human demands for fresh water rise and as climate change affects hydrology.

Shortening and simplification of the shoreline

By eliminating small irregularities in the shoreline (bays, peninsulas), straightening channels, and removing islands and side channels, humans have greatly shortened the length of many freshwater shorelines (Fig. 19), simplified their structure in map view, and reduced long-shore habitat heterogeneity. Dramatic changes have been documented in many large rivers (e.g., Sedell and Froggatt 1984; Gurnell and Petts 2002; Tockner and Stanford 2002; Jungwirth et al. 2005; Scholten et al. 2005; Miller et al. 2006). Presumably, similar but smaller changes have occurred along lake shorelines. Shortening and simplifying the shoreline probably has strong effects on the ecology of the shore zone because it reduces the area of the highly interactive land-water interface, eliminates sites of long hydraulic retention (backwaters), and reduces the habitat heterogeneity of the shore zone. Changes as large as those shown in Fig. 20 must have had very large ecological effects, even

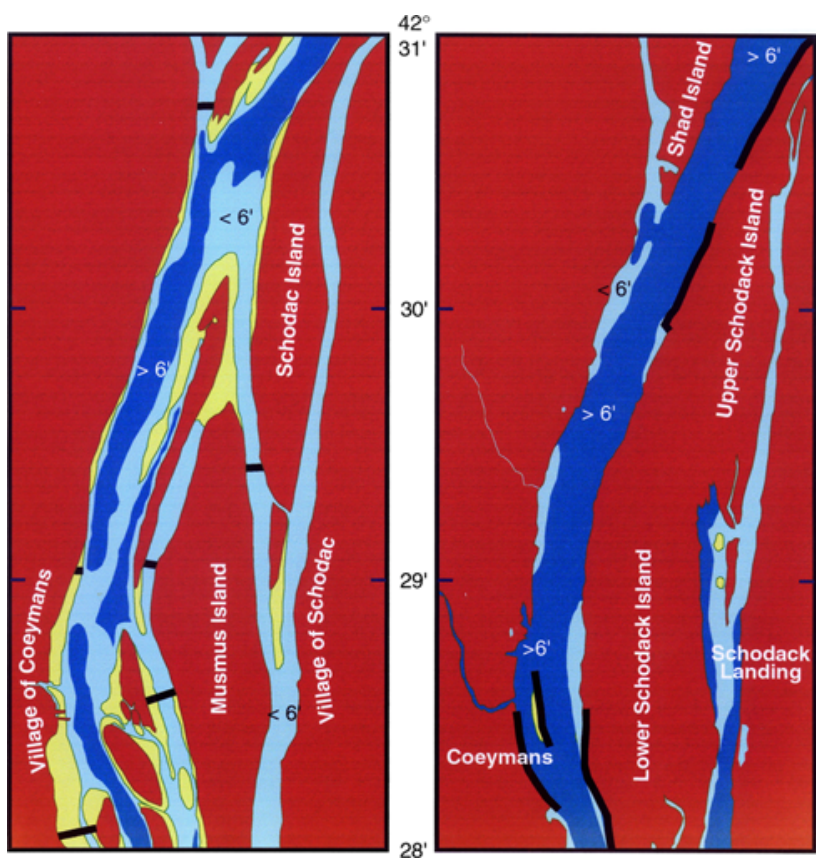

Fig. 19 Modification of the shore zone of a $5-\mathrm{km}$ reach of the freshwater tidal Hudson River between the years 1,820 (left) and 1,970 (right). Red $=$ dry land, yellow $=$ intertidal zone (the tidal range is $1-2 \mathrm{~m})$, light blue $=$ shallow water $(<1.8 \mathrm{~m}$ deep at low tide $)$, dark blue $=$ deep water $(>1.8 \mathrm{~m}$ deep at low tide $)$, heavy black lines $=$ dikes or bulkheads. From Jackson et al. (2005), after Ladd, Miller, and Nieder (color figure online) 


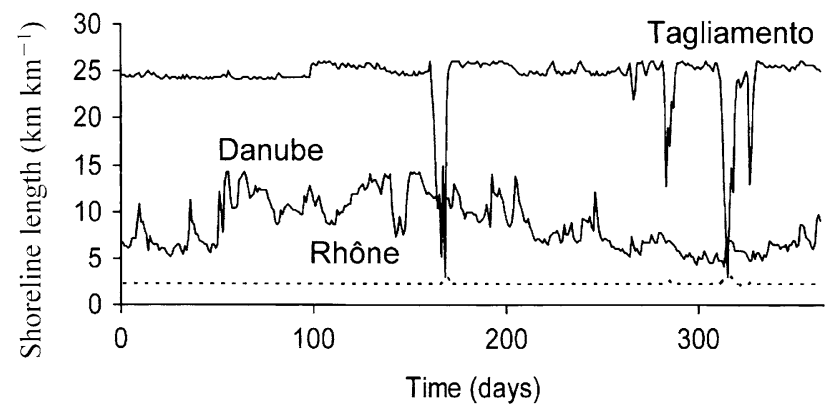

Fig. 20 Seasonal changes in the shoreline length ( $\mathrm{km}$ of shoreline per $\mathrm{km}$ of river) in a natural river (Tagliamento), a modified river (Danube), and a channelized river (Rhone), showing the huge reductions in shoreline length caused by human modifications (Tockner and Stanford 2002)

though these effects seem not to have been quantified. Some restoration projects are specifically designed to add back some of this shoreline complexity to enhance biodiversity (Hein et al. 2004; Chovanec et al. 2005).

Hardening of the shoreline

Humans have hardened many shorelines to protect them against erosion. Hardening may involve the construction of seawalls or revetments of concrete, stone, or steel; wooden bulkheads; armoring the shore with riprap or dressed stone, or other devices. Such shoreline modification has been extensive in many parts of the developed world, to the extent that artificially hardened shores dominate many shorelines. For instance, $\sim 50 \%$ of the shoreline of Sydney Harbor and the freshwater tidal Hudson River, and $80 \%$ of the shoreline of the Lake of Geneva is artificial (Bänziger 1995; Moreira et al. 2006; HRNERR, unpublished); most of this change involved shoreline hardening. Artificially hardened shorelines can differ dramatically from their natural antecedents in many ways, depending on their construction. Most artificially hardened shorelines reflect more energy than natural shorelines, which may increase sediment resuspension and scour the nearshore zone, thereby altering the biota and biogeochemistry of this region. In most cases, the hardened shoreline provides a vastly different habitat than the natural shoreline it replaced, in terms of slope, particle size, nutrient content, organic content, and physical complexity. It usually can be expected to produce a largely novel shoreline biota (except in cases where a stone or bedrock shore is replaced by an artificial hard shore, but even in such cases the biota on the artificial shoreline often is distinctive-Chapman 2003; Bulleri et al. 2005; Moschella et al. 2005). By design, hardened shores are more stable than the natural shores that they replace; because disturbance plays an important role in the functioning of shore zone ecosystems, this stability also will change the shore zone biota and biogeochemistry. Further, it seems likely that hardened shores generally impede exchanges between the aquatic and terrestrial parts of the shore zone (e.g., groundwater flow, migration of aquatic biota such as nesting turtles onto the shore, use of the water by terrestrial biota). Thus, the artificial hardening of shorelines probably has profoundly influenced shore zone ecosystems, although this has not been well quantified.

\section{Tidying of the shore zone}

Humans tidy shore zones, especially those used for recreation or housing. This tidying may involve removal of wrack, woody debris, or terrestrial or aquatic vegetation. It is well established that wrack, woody debris, and vegetation all play important ecological roles in the shore zone (see above), so it is unsurprising that shore zones that have been tidied for recreation or housing have a different ecological structure and function than natural shore zones (Fig. 3; Christensen et al. 1996; Malm et al. 2004).

Increasing inputs of physical energy

High inputs of physical energy endanger many human uses of the shore zone. It is therefore ironic that several common human activities tend to increase inputs of energy onto the shore. For example, we often build shorelines out into higher energy settings away from the existing shoreline. Nearshore dredging removes shallow-water sediments and vegetation that could have dissipated wave energy (cf. Miles et al. 2001; Miles and Russell 2004). Seawall construction deepens the region in front of the seawall, again removing sediments and vegetation that could have absorbed wave energy. Seawalls also reflect wave energy to a much greater degree than most natural shores. Of course, wakes from recreational boating and commercial navigation may significantly increase energy inputs to the shore (e.g., Bauer et al. 2002; Hofmann et al. 2008). As a result of all of these actions, we turn shorelines that did not need protection against erosion into shorelines that need engineering protection from increased wave energy.

Increasing physical energy in the shore zone also has ecological consequences. Vegetation will be uprooted or prevented from establishing, and the animals that depend on this vegetation will decline. If it is not protected, erosion of the shoreline will disrupt the terrestrial side of the shore zone and increase turbidity on the aquatic side of the shore zone, further endangering submerged vegetation and the fauna that it supports. High inputs of energy may prevent animals from maintaining desired positions in the water or even wash them onto the shore (Adams et al. 1999; Wolter and Arlinghaus 2003). 
Pollution

Shore zones are subject to all of the kinds of pollution that other ecosystems receive, but also are particularly subject to pollution by materials that float on the water. This includes plastics, which are ubiquitous and abundant in many marine shore zones (e.g., Derraik 2002; Thompson et al. 2004), as well as oil and other hydrophobic liquids. Plastics are unsightly, and kill marine animals by entangling them or blocking their digestive tracts (Derraik 2002). Microscopic plastic particles, such as those used in "scrubbers" (plastic particles $<0.5 \mathrm{~mm}$, used in hand cleaners, cosmetics, and cleaning media) or resulting from the fragmentation of larger items or the degradation of some "biodegradable" plastics, are abundant in marine shore zones (Derraik 2002; Thompson et al. 2004). These small particles can be ingested by many kinds of animals, possibly moving PCBs and other contaminants into the food web (Derraik 2002). Plastic contamination of freshwater shore zones seems not to have received much study. The amount and kind of plastics should be very variable across freshwater shore zones, depending upon the activities in the catchment. Of course, oils and other hydrophobic liquids end up in the shore zone, where they can kill animals and contaminate the biota (Thompson et al. 2002).

\section{Recreational activities}

Recreation and tourism are now regarded as leading threats to shore zones in both marine and fresh waters (Thompson et al. 2002; Schmieder 2004). Visitors attracted to popular sites in the shore zone may cause substantial ecological damage (e.g., Povey and Keough 1991; Brosnan and Crumrine 1994; Eckrich and Holmquist 2000; Pinn and Rodgers 2005; Davenport and Davenport 2006; Rossi et al. 2007). Trampling damages vegetation; kills or dislodges plants and animals from the rocky intertidal, shifting community structure from branching algae to encrusting or turf species; and kills subtidal seagrasses and bivalves. Damage to subtidal communities may be more severe in soft muds than in firm sands (Eckrich and Holmquist 2000). Hikers, swimmers, and bird-watchers sometimes (but not always) reduce populations of birds in the shore zone (van der Zande and Vos 1984; Cardoni et al. 2008; Trulio and Sokale 2008). Likewise, off-road vehicles kill beach vegetation, crush animals (Schlacher et al. 2008a, b), and compact sediments. Some of these damaged communities recover within months after trampling or vehicle traffic is stopped, but in other cases recovery may take several years. Damage from trampling and vehicles is regarded as a serious and growing problem along marine coasts, and has led to regulation and public education. Little attention has been paid to how trampling or vehicles might affect biogeochemical functioning in the shore zone. Likewise, almost all of the research on the impacts of trampling or vehicles has been conducted along marine shores. While it seems likely that many of the same impacts occur along freshwater shores (Schmieder 2004), some of the impacts that have been described pertain specifically to the distinctive marine intertidal biota, which has no analogue in fresh water, and may not occur along freshwater shores.

Wakes from recreational boats (as well as commercial ships) cause shoreline erosion and increase nearshore turbidity (Asplund 2000; Bauer et al. 2002; Hofmann et al. 2008). Further, turbulence and wakes from recreational boats and ferries damage aquatic vegetation (Ali et al. 1999; Asplund 2000; Doyle 2001; Eriksson et al. 2004; Sandström et al. 2005) and thereby reduce populations of fish that depend on this vegetation (Sandström et al. 2005), and alter macroinvertebrate communities (Bishop 2007). In very shallow water, propeller scarring may be important (e.g., Asplund 2000; Burfeind and Stunz 2006; Hammerstrom et al. 2007). Recreational watercraft (small outboards and personal watercraft) may disturb animals using the shore zone (Asplund 2000; Rodgers and Schwikert 2002; Stolen 2003) and produce pollution as well (Lico 2004). Emission controls on the small engines that power these craft often are poor (Davenport and Davenport 2006), and the large amounts of unburned hydrocarbons and PAHs released by these engines may contaminate shore zone sediments and biota. In lakes and rivers that are heavily used by recreational boaters, these combined impacts may be substantial, although they seem not often to have been assessed.

\section{Extraction of resources from the shore zone}

Humans have extracted resources from freshwater shore zones for thousands of years. Some of the most important of these resources are sand and gravel, wrack, driftwood, various kinds of plants (timber, reeds, edible plants), shellfishes, fishes, turtles, waterfowl, wading birds (for plumes), and fur-bearing mammals. Harvest rates have been very large in some times and places, and probably exceeded the threshold of sustainability. Many of these extractive industries have dwindled or disappeared in Europe and North America, but continue in other parts of the world. The individual or combined effects of these extractive uses on ecological functioning of freshwater shore zones seem not to have been well studied.

\section{Alien species}

Introductions of alien species (species that are deliberately or accidentally moved out of their native ranges by human 
actions) have large ecological and economic effects in ecosystems around the world (e.g., Lodge et al. 2006; Lockwood et al. 2007), and freshwater shore zones now support many alien species with strong impacts (e.g., zebra mussels in North America, muskrats in Europe, tamarisk in the American West, common carp in North America and Australia, invasive clones of Phragmites australis in North America). Some ecologists (Pyšek and Prach 1993; PlantyTabacchi et al. 1996; Hill et al. 1998; Bunn and Arthington 2002; Airoldi and Beck 2007) have suggested that shore zones are particularly prone to invasion because of high rates of natural and human-caused disturbance, close contact between humans and shore zones, and effectiveness of the shore zone as a dispersal corridor for alien species. For instance, Planty-Tabacchi et al. (1996) found that 23-30\% of the plant species in riparian zones in France and the Pacific Northwest were aliens, and alien species constituted $56 \%$ of species and $40 \%$ of cover in marine shore zones in Rhode Island (Bruno et al. 2004).

Regardless of whether shore zones are more susceptible than other types of ecosystems to invasion or impacts of alien species, it is clear that shore zones have been strongly affected by alien species, and that these impacts are likely to intensify in the future as new aliens establish themselves, and established aliens spread throughout shore zones. Eradication or management of established alien species can be difficult or impossible (Rejmánek et al. 2005; Lodge et al. 2006), so some (e.g., Winfield 2004) have argued that it is important to prevent aliens from getting established in the first place.

\section{Climate change}

Humans have now begun to affect the climate, and these effects are projected to accelerate over the next few decades (IPCC 2007). Anthropogenic climate change will affect shore zone ecosystems in several ways. Sea-level rise, projected to be at least $18 \mathrm{~cm}$ and perhaps much more in the twenty-first century (IPCC 2007) will affect marine shore zones as well as coastal or tidal freshwater shore zones. Sea-level rise should raise mean water levels, increase the frequency of floods, increase salinity, and increase sedimentation in these shore zones. Rising air temperatures should accelerate rates of biogeochemical processes in many freshwater shore zones. Other important effects on freshwater shore zones are likely to occur, but will be more idiosyncratic and difficult to predict. Changes in temperature and precipitation will cause water levels to rise or fall, and some have projected that extreme events (droughts and floods) will become more frequent and more severe. Both changes in climate and subsequent changes in hydrology will probably have strong effects on the composition, distribution, and abundance of the shore zone biota (e.g., Hijmans and Graham 2006), but the details of such changes and the changes that they will in turn cause to shore zone morphology and biogeochemistry are unknown. Humans will almost certainly respond to climate change by intensifying management and engineering of shore zones to protect property. It is possible that the effects of human engineering responses to climate change (e.g., coastal squeeze, shoreline hardening, levees, hydrological modifications) will cause greater ecological changes to freshwater shore zones than the direct effects of climate change itself.

\section{Building in the shore zone}

The intensification of human development in the shore zone will have a number of important ecological effects, in addition to effects addressed above. The increase in impervious surfaces will tend to increase local flooding and alter pathways of groundwater flow in the shore zone, with consequent effects on biogeochemical processing and habitat quality. Human activities will provide a local source of toxins, including pesticides, petroleum products, pharmaceuticals, and many other compounds to developed shore zones. Rates of introductions of alien species to the shore zone will increase as these species are used in landscaping, released from captivity, or are transported in commerce. The increased artificial lighting associated with human settlements and buildings will affect the shore zone biota, perhaps leading to nuisance accumulations of emerging aquatic insects (Rich and Longcore 2005). Structures built along dispersal corridors in the shore zone may kill birds and other migrating animals.

Engineering shore zones to enhance ecological services

Humans have long engineered shore zones for specific purposes (e.g., to prevent erosion or flooding, to enhance crop production). As the ecological services provided by shore zones have received greater visibility, it has been natural to ask whether shore zones could be engineered to increase the ecological services that they provide while at the same time satisfying human needs for flood control, etc. The ecological engineering of shore zones is still a young field, and has been focused mainly on marine shores (e.g., Airoldi et al. 2005; Martin et al. 2005; National Research Council 2007; Chapman and Blockley 2009). Marine ecologists have made suggestions about which design features of engineered structures will affect their ecological value (Table 1), as well as principles that might be used to manage shore zones taking ecological services into account (Table 2). There have been a few attempts to assess the ecological value of different kinds of structures in freshwater shore zones as well (Fladung 2002; Scholten 2002; Chovanec et al. 2005; Kleinwächtler et al. 2005; Scholten et al. 2005). 
Table 1 Design features of low-crested coastal defense structures that affect their ecological functioning (modified from Airoldi et al. 2005)

\begin{tabular}{|c|c|}
\hline Feature & Effects \\
\hline Amount & If structures are numerous, they can have large-scale effects \\
\hline Location & $\begin{array}{l}\text { Geographic context and local habitat set local species pool, } \\
\text { which affects ecological responses to added structure }\end{array}$ \\
\hline Spatial arrangement & $\begin{array}{l}\text { Distance from other artificial structures and similar natural } \\
\text { habitats affects dispersal of species onto added structure }\end{array}$ \\
\hline Height, size, and porosity & $\begin{array}{l}\text { Affects local hydrodynamics and sediment dynamics, which } \\
\text { affect ecological responses }\end{array}$ \\
\hline Lifetime and structural integrity & Frequent disturbance favor opportunistic species \\
\hline Material and physical complexity & Affect local distribution of biota and biogeochemical activities \\
\hline
\end{tabular}

Table 2 Suggested principles for the sustainable management of shore zones using low-crested coastal defense structures and other coastal defenses (modified from Airoldi et al. 2005)

\begin{tabular}{ll}
\hline Action & Comments \\
\hline Clearly define management goals & $\begin{array}{c}\text { Allows development of predictions of effects of added structure and } \\
\text { evaluation of effectiveness } \\
\text { If context is not considered carefully, undesirable downstream and } \\
\text { cumulative effects can occur } \\
\text { Downstream effects can magnify the original problem and lead to } \\
\text { proliferation of structures }\end{array}$ \\
$\begin{array}{l}\text { Minimize downstream effects } \\
\text { Proid proliferation of structures }\end{array}$ & $\begin{array}{c}\text { Alternative solutions (including "do nothing") may have fewer } \\
\text { undesirable effects, and should be considered early in planning } \\
\text { process }\end{array}$ \\
$\begin{array}{l}\text { Monsider alternatives } \\
\text { Sound long-term monitoring allows future management to be } \\
\text { improved }\end{array}$ \\
$\begin{array}{l}\text { Preserve native assemblages and processes } \\
\text { Minimize hydrodynamic disruption }\end{array}$ \\
$\begin{array}{l}\text { Minimize ongoing maintenance } \\
\text { Manage human access and use }\end{array}$ & $\begin{array}{l}\text { Allows development of mature ecological assemblages } \\
\text { Severe human disturbance can negatively affect zoobenthos and } \\
\text { plants }\end{array}$ \\
\hline
\end{tabular}

There would seem to be considerable potential to incorporate ecological considerations into the design of engineered structures in freshwater shore zones (cf. Engel and Pederson 1998). It is far too early to give firm recommendations about how best to design such structures to maximize desired ecological services, but the results reviewed above suggest some possible directions. For instance, structures that are rough or irregular in topography or plan view are likely to support higher biodiversity and biogeochemical function than perfectly smooth structures. Engineered structures that have slopes very different from the natural shore zones that they replace are likely to induce large changes in ecological function. Very steep structures not only reduce the area of the shore zone (Fig. 8), but also generally increase reflection of wave energy, which usually is undesirable. Structures that block the movement of organisms, water, or other materials, whether across the shore zone (impermeable vertical seawalls) or along the shore zone, are likely to be undesirable from an ecological point of view. Hydrological regimes that deviate greatly from the natural regime, either in magnitude or timing of water-level fluctuations, can be expected to degrade ecological functioning (cf. Poff et al. 1997; Hill et al. 1998). Likewise, structures that reduce the ability of the shore zone to produce or retain organic matter, including woody debris, may have undesirable consequences. In addition, as Doyle et al. (2008) pointed out, replacement, repair, or removal of aging infrastructure in shore zones may offer promising opportunities to improve the ecological functioning of engineered shore zones.

One concern that may arise as shore zones are deliberately engineered to provide ecological services is whether such artificially provided ecological services are as valuable as those provided by a natural shore zone (Angermeier 1994). For instance, high biodiversity is considered to be a 
desirable goal of ecosystem management. However, novel and highly artificial substrata introduced into a shore zone often support species that occur nowhere else in the system, including on natural substrata (Fig. 21). Are the species that occur on these artificial substrata valuable, or should they be dismissed as "artificial biodiversity" of little value (Angermeier 1994)? Likewise, would completely artificial structures that captured floating organic matter be considered as valuable as woody debris, from the viewpoint of organic matter retention and nutrient cycling? Such issues will need to be resolved by stakeholders and managers before engineering projects to enhance ecological services are undertaken.

\section{Values of different kinds of shore zones}

\section{Individual ecological services}

From the viewpoint of shore zone management, it would be useful to be able to estimate the ability of a particular shore zone to provide various ecological services (e.g., primary production, nitrate removal, habitat for a sport fish, etc.). This might be done by classifying shore zones into a manageable number of classes (e.g., dissipative sandy beaches, vertical seawalls, etc.) and constructing a table that gives the typical amount of each ecological services that is provided by each kind of shore zone (Table 3), or by

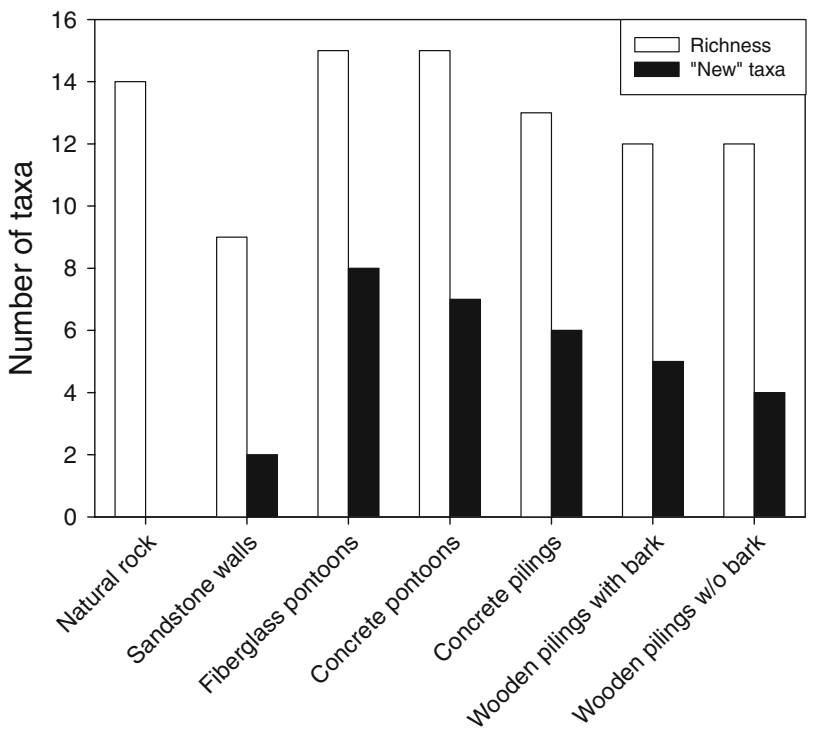

Fig. 21 Number of taxa of common macroscopic algae and animals occupying natural rocky reefs and various artificial substrata in Sydney Harbor, Australia. "New taxa" means taxa that do not occur on the natural rocky reefs, and indicate the potential of artificial substrata to enhance biodiversity at the cross-habitat scale (from data of Glasby and Connell 1999) treating shore zones as continuous and constructing a multivariate equation of the form

$v_{i}=f\left(C_{1}, C_{2}, \ldots, C_{n}\right)$

where $v_{i}$ is the amount of the $i$ th ecological service (e.g., habitat provision for a particular sport fish) and the $C$ are the important characteristics of the shore zone (e.g., slope, complexity, hydrology, etc.). At present, neither of these approaches is feasible for freshwater shore zones because of inadequate information. Many ecological services and types of shore zones have been very poorly studied, and the information we do have has been insufficiently organized and analyzed. Marine ecologists have attempted to assess the ecological services that different kinds of shore zones provide (Table 3), but these approaches still are rough, even for marine shores.

Another difficulty in estimating the ability of a shore zone to provide a particular ecological service, apart from the problem of insufficient information, is that the value of an individual bit of the shore zone depends on the context into which it is placed (Airoldi et al. 2005; Martin et al. 2005; Toft et al. 2007). The overall composition of habitats within the larger system and the strength of linkages among these habitats will help to determine the value of a unit of shore zone habitat. Thus, a hectare of rocky shoreline may provide far more value in terms of system-wide ecological services when it occurs in a predominately muddy estuary than when it occurs in an entirely rocky one. For these and other reasons, the ability of a unit of habitat to provide an ecological service often will be a nonlinear function of the amount of that habitat (cf. Barbier et al. 2008), so it will be impossible to assign a unique per hectare value to a habitat type. This is a problem of special significance when considering cumulative losses of habitat or the marginal value of restoring habitat. For the many species or ecological processes that depend on more than one habitat (e.g., Irlandi and Crawford 1997; Amoros and Bornette 2002; Robinson et al. 2002; Scholten 2002; Winfield 2004), the details of the spatial structure of the system will modify the ability of a unit of habitat to provide ecological services. Consequently, it seems unlikely that a general approach like that shown in Table 3 will ever be able to precisely estimate the value of a particular piece of the shore zone. Instead, if a precise estimate of value is needed, a special study will have to be made of each shore zone and the setting into which it is placed.

It is certainly too early to make a comprehensive assessment of the ecological values provided by different kinds of freshwater shore zones, when many of ecological functions and shore zone types have not been studied. Nevertheless, we have made a very tentative assessment of the ability of different kinds of freshwater shore zones to provide ecological services (Table 4). This assessment 
Table 3 Example of a tentative assessment of the amount of various ecosystem services provided by different kinds of marine shore lines (modified from National Research Council, 2007)

\begin{tabular}{|c|c|c|c|c|c|c|c|c|c|c|c|}
\hline & $\begin{array}{l}\text { Sandy } \\
\text { beaches }\end{array}$ & $\begin{array}{l}\text { Sand } \\
\text { dunes }\end{array}$ & Mudflats & $\begin{array}{l}\text { Marshes } \\
\text { and } \\
\text { mangroves }\end{array}$ & $\begin{array}{l}\text { Seagrasses } \\
\text { and } \\
\text { macroalgae }\end{array}$ & Bluffs & $\begin{array}{l}\text { Bulkheads } \\
\text { and } \\
\text { seawalls }\end{array}$ & Revetments & Groins & $\begin{array}{l}\text { Breakwaters } \\
\text { and sills }\end{array}$ & $\begin{array}{l}\text { Planted } \\
\text { marshes/ } \\
\text { mangroves }\end{array}$ \\
\hline Fish habitat & 1 & 1 & 2 & 3 & 3 & 1 & 1 & 2 & 1 & 3 & 3 \\
\hline Mollusk habitat & 3 & 1 & 3 & 3 & 3 & 1 & 2 & 2 & 2 & 2 & 3 \\
\hline Crustacean habitat & 2 & 1 & 2 & 3 & 3 & 1 & 0 & 1 & 1 & 1 & 3 \\
\hline Turtle habitat & 3 & 2 & 0 & 1 & 2 & 1 & 0 & 0 & 0 & 0 & 1 \\
\hline Bird habitat & 2 & 3 & 3 & 3 & 1 & 3 & 0 & & & & 3 \\
\hline Nutrient processing & 2 & 1 & 2 & 3 & 3 & 1 & 1 & 1 & 1 & 1 & 3 \\
\hline Food production & 1 & 1 & 2 & 3 & 3 & 2 & 1 & 1 & 1 & 1 & 3 \\
\hline Wave attenuation & 2 & 3 & 1 & 2 & 2 & 3 & 1 & 2 & 2 & 3 & 2 \\
\hline Sediment stabilization & 0 & 3 & 2 & 3 & 3 & 0 & & & 2 & 3 & 3 \\
\hline Gas regulation & 1 & 0 & 1 & 3 & 3 & 0 & 0 & 0 & 0 & 0 & 3 \\
\hline Biodiversity & 2 & 3 & 2 & 3 & 3 & 3 & 1 & 1 & 1 & 1 & 3 \\
\hline Recreation & 3 & 3 & 1 & 3 & 3 & 2 & 2 & 1 & 2 & 2 & 3 \\
\hline Raw materials & 3 & 3 & 1 & 3 & 3 & 3 & 1 & 1 & 1 & 1 & 3 \\
\hline Aesthetic value & 3 & 3 & 2 & 3 & 3 & 3 & 0 & 0 & 0 & 0 & 3 \\
\hline
\end{tabular}

Higher numbers indicate greater provision of services

Table 4 Tentative assessment of the ability of different kinds of freshwater shore zones to provide ecological services (cf. Table 3)

\begin{tabular}{|c|c|c|c|c|c|c|c|}
\hline & $\begin{array}{l}\text { Unvegetated } \\
\text { mud flat }\end{array}$ & $\begin{array}{l}\text { Unvegetated } \\
\text { sand beach }\end{array}$ & $\begin{array}{l}\text { Cobble or } \\
\text { bedrock }\end{array}$ & $\begin{array}{l}\text { Vegetated sand } \\
\text { or mud }\end{array}$ & Marsh & $\begin{array}{l}\text { Riprapped } \\
\text { revetment }\end{array}$ & $\begin{array}{l}\text { Steel or concrete } \\
\text { seawall }\end{array}$ \\
\hline Habitat for aquatic plants & 0 & 0 & + & +++ & +++ & + & 0 \\
\hline Habitat for aquatic invertebrates & ++ & ++ & +++ & +++ & +++ & ++ & + \\
\hline Habitat for fishes & + & + & ++ & +++ & +++ & ++ & + \\
\hline Habitat for birds & ++ & ++ & ++ & +++ & +++ & ++ & 0 \\
\hline Energy dissipation & ++ & ++ & ++ & +++ & +++ & ++ & + \\
\hline Primary production & + & + & + & +++ & +++ & + & 0 \\
\hline $\begin{array}{l}\text { Retention or decomposition of } \\
\text { organic matter }\end{array}$ & ++ & ++ & ++ & +++ & +++ & ++ & 0 \\
\hline Nutrient transformation & ++ & ++ & ++ & +++ & +++ & + & 0 \\
\hline Biotic dispersal & ++ & ++ & ++ & +++ & +++ & ++ & + \\
\hline
\end{tabular}

should be taken as hypothetical, and tested before it is applied.

Integrating multiple ecological services

Because shore zones provide so many kinds of ecological and economic services, it would be useful to be able to produce a single index of the overall ecological value of a shore zone to aid in prioritizing sites for conservation or management, assessing alternative plans for management or rehabilitation, or other purposes. There have been several attempts to produce such indices (e.g., Ostendorp 2004; Hostmann et al. 2005; Ludwig and Iannuzzi 2006; Reichert et al. 2007; Barbier, et al. 2008), but all suffer from more or less serious difficulties.
Broadly speaking, such indices combine information about provision of various ecological services by a shore zone with human valuation of those services. The first difficulty with such an approach is in estimating all of the ecological services provided by a particular bit of the shore zone. As we have seen, the services that shore zones provide are numerous and highly varied (biodiversity of various taxa, biogeochemical transformations of various substances, recreation, etc.) and have probably never been adequately estimated for any specific shore zone. Consequently, attempts to consider multiple ecological services (e.g., Ludwig and Iannuzzi 2006) typically have been based on a limited range of services.

Second, it can be tricky to convert from ecological services, however estimated, and human valuation of those 
services. One approach is to consider the overall value of a shore zone to be the weighted sum of the values of all of the ecological services that it provides. Thus,

$V\left(S_{j}\right)=\sum_{i} w_{i} v_{i}\left(a_{i j}\right)$

where $V\left(S_{j}\right)$ is the overall value of the $j$ th shore zone, $w_{i}$ is the weight (relative value) that stakeholders place on the $i$ th ecological service relative to other services provided by that shore zone, and $v_{i}\left(a_{i j}\right)$ is the value function for the $i$ th ecological service (i.e., the relative value of different amounts $a_{i j}$ of that particular service). In theory, this approach (which follows Hostmann et al. 2005) allows one to calculate the relative value of different shore zones, different rehabilitation proposals, etc. In fact, this approach can be difficult to apply in practice. In addition to the difficulties just discussed in estimating the $a_{i j}$, it is necessary to estimate the value functions for each ecological service as well as the relative weights of the different services. Value functions and weights often will vary greatly across stakeholders (bird biodiversity will be highly valued by some users of the shore zone but not by others) and are assumed not to interact (i.e., the value of a shore zone for recreational angling is assumed not to depend on the aesthetic appeal of the site). Hostmann et al. (2005) dealt with the former problem by estimating value functions and weights independently for different stakeholder groups (recreationalists, farmers, government officials). This reasonable solution then leads to another problem-how to resolve the inevitable differences in $V\left(S_{j}\right)$ estimated by the different stakeholder groups. Again, Hostmann et al. (2005) discussed the merits of different ways to resolve such conflicts.

It would be very helpful to have practical, reliable approaches to estimate or at least rank the overall value of different kinds of shore zones to guide planning, protection, management, and rehabilitation. Such approaches will need to be based on good estimates of the ecological services provided by different shore zones (including a broad range of services), careful consideration of the values that different stakeholders place on these services, and some system of conflict resolution.

\section{Conclusions}

Enough is known about freshwater shore zones and the ecological services that they provide to improve the protection, management, and rehabilitation of these important ecosystems. Nevertheless, there are prominent gaps in our knowledge. We mention just three of these gaps, and highlight an opportunity to fill these gaps.

First, much of our knowledge is too general to be applied to the management of specific sites and services.
Management questions often are very specific (will restoring 0.6 ha of marsh at site $\mathrm{X}$ on river $\mathrm{Y}$ increase the population size or growth rate of fish species Z?). Few of our theories about the workings of shore zones are so powerful and free of context-dependence that they can provide adequate answers to such specific questions. Instead, we should expect to have to conduct site- and species-specific studies if we really want precise answers to many management questions. Perhaps it will eventually be possible to build general empirical models that provide sufficiently precise answers, but at present it seems likely that precise questions will require site-specific analyses.

Second, because the ecology of marine shore zones is so much better understood than that of freshwater shore zones, there will be a natural tendency to apply ideas and models developed for marine shore zones to freshwater shore zones. There are both significant similarities and significant differences between marine and freshwater shore zones. Which marine paradigms can be safely applied to freshwater shore zones, which must be modified, and which should be rejected? For instance, can interannual fluctuations in water level be substituted for relative tidal range in models of shore zone morphology and ecology? We suggest that freshwater ecologists and managers actively seek out and use ideas from marine ecology, but insist that these ideas be tested on freshwater shore zones before they are widely applied.

Third, almost all studies of shore zones, whether marine or freshwater, have focused on individual bits of the shore zone, rather than on a larger system (a biological population, a coastal habitat complex, etc.). Yet it is the larger system that is most often the target of our management efforts, and which is vulnerable to the cumulative effects of changes in many bits of the shore zone or the effects of a change that are propagated to distant parts of the system by physical or biological vectors (currents, migrations). This is a hard problem that applies to many parts of ecology (Lovett et al. 2005), and appears to have no easy solutions. The fact that the problem is difficult does not excuse us from addressing it. Shore zone ecologists will need to develop ways to understand how changes in individual bits of the shore zone alter the larger system of interest.

People are conducting countless experiments on shore zones every day, in the name of management or development activities. These activities offer powerful opportunities for rapid scientific progress. If we are serious about learning enough about shore zone ecosystems to manage them intelligently, then we need to take better advantage of these opportunities. When shore zones are developed, coastal defenses are built, or habitats are restored, we should treat them more like scientific experiments. We should insist that good pre- and post-project 
data on ecological functions are collected, and look for opportunities to include experimental treatments as part of routine activities in shore zones. For instance, if a revetment is built to protect a shoreline from erosion, perhaps a small section could be built of a different material or a different roughness thought to improve ecological functioning. Collecting such data more systematically could trigger a quantum advance in the understanding and management of shore zones.

Acknowledgments We are grateful to the Hudson River National Estuarine Research Reserve (HRNERR) and the Hudson River Foundation for providing funding to support the preparation of this review, to Betsy Blair, Dan Miller, Klement Tockner, and our colleagues at the Cary Institute for helpful discussions and ideas about the ecology of shore zones, to Amy Schuler for help in locating references, to the USGS for providing water-level data, and to HRNERR staff for helpful comments on an earlier draft.

Open Access This article is distributed under the terms of the Creative Commons Attribution Noncommercial License which permits any noncommercial use, distribution, and reproduction in any medium, provided the original author(s) and source are credited.

\section{References}

Adams SR, Keevin TM, Killgore KJ, Hoover JJ (1999) Stranding potential of young fishes subjected to simulated vessel-induced drawdown. Trans Am Fish Soc 128:1230-1234

Addy K, Gold A, Nowicki B, McKenna J, Stolt M, Groffman P (2005) Denitrification capacity in a subterranean estuary below a Rhode Island fringing salt marsh. Estuaries 28:896-908

Ailstock MS, Norman CM, Bushman PJ (2001) Common reed Phragmites australis: control and effects on biodiversity in freshwater nontidal wetlands. Restor Ecol 9:49-59

Airoldi L, Beck MW (2007) Loss, status and trends for coastal marine habitats of Europe. Oceanogr Marine Biol Annu Rev 45:345405

Airoldi L, Abbiati M, Beck MW, Hawkins SJ, Jonsson PR, Martin D, Moschella PS, Sundelof A, Thompson RC, Aberg P (2005) An ecological perspective on the deployment and design of lowcrested and other hard coastal defence structures. Coast Eng 52:1073-1087

Ali MM, Murphy KJ, Langendorff J (1999) Interrelationships of river ship traffic with aquatic plants in the River Nile, Upper Egypt. Hydrobiologia 415:93-100

Amoros C, Bornette G (2002) Connectivity and biocomplexity in waterbodies of riverine floodplains. Freshw Biol 47:761-776

Angermeier PL (1994) Does biodiversity include artificial diversity? Conserv Biol 8:600-602

Angradi TR, Schweiger EW, Bolgrien DW, Ismert P, Selle T (2004) Bank stabilization, riparian land use and the distribution of large woody debris in a regulated reach of the upper Missouri River, North Dakota, USA. River Res Appl 20:829-846

Arscott DB, Tockner K, Ward JV (2005) Lateral organization of aquatic invertebrates along the corridor of a braided floodplain river. J North Am Benthol Soc 24:934-954

Asplund TR (2000) The effects of motorized watercraft on aquatic ecosystems. Wisconsin Department of Natural Resources PUBLSS-948-00. Madison, WI
Backlund HO (1945) Wrack fauna of Sweden and Finland: ecology and chorology. Opuscula Entomologica Supplementum 5:236 ( +6 plates)

Baldwin DS, Mitchell AM (2000) The effects of drying and reflooding on the sediment and soil nutrient dynamics of lowland river-floodplain systems: a synthesis. Regulated Rivers: Research and Management 16:457-467

Bänziger R (1995) A comparative study of the zoobenthos of eight land-water interfaces (Lake of Geneva). Hydrobiologia 300/ 301:133-140

Baptist MJ, van den Bosch L, Dijkstra JT, Kapinga S (2005) Modelling the effects of vegetation on flow and morphology in rivers. Archiv für Hydrobiologie Supplementband 155:339-357

Barbier EB, Koch EW, Silliman BR, Hacker SD, Wolanski E, Primavera J, Granek EF, Polasky S, Aswani S, Cramer LA, Stoms DM, Kennedy CJ, Bael D, Kappel CV, Perillo GME, Reed DJ (2008) Coastal ecosystem-based management with nonlinear ecological functions and values. Science 319:321-323

Barton DR, Hynes HBN (1978) Wave-zone macrobenthos of the exposed Canadian shores of the St. Lawrence Great Lakes. J Great Lakes Res 4:27-45

Barwick DH (2004) Species richness and centrarchid abundance in littoral habitats of three southern U.S. reservoirs. North Am J Fish Manag 24:76-81

Barwick RD, Kwak TJ, Noble RL, Barwick DH (2004) Fish populations associated with habitat-modified piers and natural woody debris in Piedmont Carolina reservoirs. North Am J Fish Manag 24:1120-1133

Bastow JL, Sabo JL, Finlay JC, Power ME (2002) A basal aquaticterrestrial trophic link in rivers: algal subsidies via shoredwelling grasshoppers. Oecologia 131:261-268

Battle JM, Golladay SW (2001) Hydroperiod influence on breakdown of leaf litter in a cypress-gum wetland. Am Midl Nat 146:128 145

Bauer BO, Lorang MS, Sherman DJ (2002) Estimating boat-wakeinduced levee erosion using sediment suspension measurements. J Waterw Port Coast Ocean Eng 128:152-162

Bayley PB (1995) Understanding large river-floodplain ecosystems. Bioscience 45:153-158

Begin Y, Payette S (1991) Population structure of lakeshore willows and ice push events in sub-Arctic Quebec, Canada. Holarctic Ecol 14:9-17

Behbehani MI, Croker RA (1982) Ecology of beach wrack in northern New England with special reference to Orchestia platensis. Estuar Coast Shelf Sci 15:611-620

Bell EC, Denny MW (1994) Quantifying “wave exposure”: a simple device for recording maximum velocity and results of its use at several field sites. J Exp Mar Biol Ecol 181:9-29

Benke AC, Wallace JB (2003) Influence of wood on invertebrate communities in streams and rivers. In: Gregory SV, Boyer KL, Gurnell AM (eds) The Ecology and Management of Wood in World Rivers. American Fisheries Society Symposium, Bethesda, MD, pp 149-177

Benson BJ, Magnuson JJ (1992) Spatial heterogeneity of littoral fish assemblages in lakes: relation to species diversity and habitat structure. Can J Fish Aquat Sci 49:1493-1500

Bertness MD (1999) The ecology of Atlantic shorelines. Sinauer Associates, Sunderland, $417 \mathrm{pp}$

Bertness MD, Ewanchuk PJ, Silliman BR (2002) Anthropogenic modification of New England salt marsh landscapes. Proc Natl Acad Sci 99:1395-1398

Bishop MJ (2007) Impacts of boat-generated waves on macroinfauna: towards a mechanistic understanding. J Exp Mar Biol Ecol 343:187-196

Boers AM, Zedler JB (2008) Stabilized water levels and Typha invasiveness. Wetlands 28:676-685 
Bolding B, Bonar S, Divans M (2004) Use of artificial structure to enhance angler benefits in lakes, ponds, and reservoirs: a literature review. Rev Fish Sci 12:75-96

Bowen KL, Kaushik NK, Gordon AM (1998) Macroinvertebrate communities and biofilm chlorophyll on woody debris in two Canadian oligotrophic lakes. Archiv für Hydrobiologie 141:257281

Bowers R, de Szalay FA (2005) Effects of water level fluctuations on zebra mussel distribution in a Lake Erie coastal wetland. J Freshw Ecol 20:85-92

Brauns M, Garcia X-F, Walz N, Pusch MT (2007) Effects of human shoreline development on littoral macroinvertebrates in lowland lakes. J Appl Ecol 44:1138-1144

Brazeiro A (2001) Relationship between species richness and morphodynamics in sandy beaches: what are the underlying factors? Mar Ecol Prog Ser 224:35-44

Brinkhurst RO (1974) The benthos of lakes. St. Martin's Press, New York, $190 \mathrm{pp}$

Brittain JE, Lillehammer A (1978) The fauna of the exposed zone of Øvre Heimdalsvatn: methods, sampling stations, and general results. Holarctic Ecology 1:221-228

Brodersen KP (1995) The effect of wind exposure and filamentous algae on the distribution of surf zone macroinvertebrates in Lake Esrom, Denmark. Hydrobiologia 297:131-148

Brosnan DM, Crumrine LL (1994) Effects of human trampling on marine rocky shore communities. J Exp Mar Biol Ecol 177:79-97

Brown AC, McLachlan A (2002) Sandy shore ecosystems and the threats facing them: some predictions for the year 2025. Environmental Conservation 29:62-77

Bruno JF, Kennedy CW, Rand TA, Grant MB (2004) Landscape-scale patterns of biological invasions in shoreline plant communities. Oikos 107:531-540

Bulleri F, Airoldi L (2005) Artificial marine structures facilitate the spread of a non-indigenous green alga, Codium fragile ssp. tomentosoides, in the north Adriatic Sea. J Appl Ecol 42:10631072

Bulleri F, Chapman MG, Underwood AJ (2005) Intertidal assemblages on seawalls and vertical rocky shores in Sydney Harbour, Australia. Austral Ecol 30:655-667

Bunn SE, Arthington AH (2002) Basic principles and ecological consequences of altered flow regimes for aquatic biodiversity. Environ Manage 30:492-507

Burfeind DD, Stunz GW (2006) The effects of boat propeller scarring on nekton abundance in subtropical seagrass meadows. Mar Biol 148:953-962

Burlakova LE, Karatayev AY (2007) The effect of invasive macrophytes and water level fluctuations on unionids in Texas impoundments. Hydrobiologia 586:291-302

Cardoni DA, Favero M, Isacch JP (2008) Recreational activities affecting the habitat use by birds in Pampa's wetlands, Argentina: implications for waterbird conservation. Biol Conserv 141:797-806

Carlton JT, Hodder J (2003) Maritime mammals: terrestrial mammals as consumers in intertidal communities. Mar Ecol Prog Ser 256:271-286

Chambers PA (1987) Nearshore occurrence of submersed aquatic macrophytes in relation to wave action. Can J Fish Aquat Sci 44:1666-1669

Chambers RM, Havens KJ, Killeen S, Killeen S, Berman M (2008) Common reed Phragmites australis occurrence and adjacent land use along estuarine shoreline in Cheasapeake Bay. Wetlands 28:1097-1103

Chapman MG (2003) Paucity of mobile species on constructed seawalls: effects of urbanization on biodiversity. Mar Ecol Prog Ser 264:21-29
Chapman MG, Blockley DJ (2009) Engineering novel habitats on urban infrastructure to increase intertidal biodiversity. Oecologia 161:625-635

Chapman MG, Bulleri F (2003) Intertidal seawalls-new features of the landscape in intertidal environments. Landsc Urban Plann 62:159-172

Chovanec A, Straif M, Waidbacher H, Schiemer F, Cabela A, Raab R (2005) Rehabilitation of an impounded section of the Danube in Vienna (Austria)-evaluation of inshore structures and habitat diversity. Archiv für Hydrobiologie Supplementband 155:211224

Christensen DL, Herwig BR, Schindler DE, Carpenter SR (1996) Impacts of lakeshore residential development on coarse woody debris in North Temperate lakes. Ecol Appl 6:1143-1149

Cochran JL, Cochran PA (2005) Use of fallen trees for spawning by the spotfin shiner (Cyprinella spiloptera) in the upper Mississippi River. J Freshw Ecol 20:771-773

Cole JJ, Findlay S, Pace ML (1988) Bacterial production in fresh and saltwater ecosystems: a cross-system overview. Mar Ecol Prog Ser 43:1-10

Colombini I, Chelazzi L (2003) Influence of marine allochthonous input on sandy beach communities. Oceanogr Mar Biol Annu Rev 41:115-159

Coops H, Boeters R, Smit H (1991) Direct and indirect effects of wave attack on helophytes. Aquat Bot 41:333-352

Coops H, Geilen N, vander Velde G (1994) Distribution and growth of the helophyte species Phragmites autralis and Scirpus lacustris in water depth gradients in relation to wave exposure. Aquat Bot 48:273-284

Coops H, Geilen N, Verheij HJ, Boeters R, vander Velde G (1996) Interactions between waves, bank erosion and emergent vegetation: an experimental study in a wave tank. Aquat Bot 53:187198

Coops H, Vulink JT, van Nes EH (2004) Managed water levels and the expansion of emergent vegetation along a lakeshore. Limnologica 34:57-64

Coupland GT, Duarte CM, Walker DI (2007) High metabolic rates in beach cast communities. Ecosystems 10:1341-1350

Crook DA, Robertson AI (1999) Relationships between riverine fish and woody debris: implications for lowland rivers. Mar Freshw Res 50:941-953

Cushman RM (1985) Review of ecological effects of rapidly varying flows downstream from hydroelectric facilities. North Am J Fish Manag 5:330-339

Dacey JWH (1981) Pressurized ventilation in the yellow water lily. Ecology 62:1137-1147

Dall PC, Lindegaard C, Jónsson E, Jónsson G, Jónasson PM (1984) Invertebrate communities in the exposed littoral zone of Lake Esrom, Denmark. Archiv für Hydrobiologie Supplementband 69:477-524

Davenport J, Davenport JL (2006) The impact of tourism and personal leisure transport on coastal environments: a review. Estuar Coast Shelf Sci 67:280-292

Defeo O, McLachlan A (2005) Patterns, processes and regulatory mechanisms in sandy beach macrofauna: a multi-scale analysis. Mar Ecol Prog Ser 295:1-20

Denny MW (1988) Biology and the mechanics of the wave-swept environment. Princeton University Press, Princeton, $344 \mathrm{pp}$

Derraik JGB (2002) The pollution of the marine environment by plastic debris: a review. Mar Pollut Bull 44:842-852

Dionne JC (1993) Sediment load of shore ice and ice rafting potential, upper St. Lawrence estuary, Quebec, Canada. J Coastal Res 9:628-646

Doyle RD (2001) Effects of waves on the early growth of Vallisneria americana. Freshw Biol 46:389-397 
Doyle MW, Stanley EH, Havlick DG, Kaiser MJ, Steinbach G, Graf WL, Galloway GE, Riggsbee JA (2008) Aging infrastructure and ecosystem restoration. Science 319:286-287

Dugan JE, Hubbard DM, McCrary MD, Pierson MO (2003) The response of macrofauna communities and shorebirds to macrophyte wrack subsidies on exposed sandy beaches of southern California. Estuar Coast Shelf Sci 58:25-40

Eckrich CE, Holmquist JG (2000) Trampling in a seagrass assemblage: direct effects, response of associated fauna, and the role of substrate characteristics. Mar Ecol Prog Ser 201:199-209

Ekebom, Laihonen JP, Suominen T (2003) A GIS-based step-wise procedure for assessing physical exposure in fragmented archipelagos. Estuar Coast Shelf Sci 57:887-898

Elias SP, Fraser JD, Buckley PA (2000) Piping plover brood foraging ecology on New York barrier islands. J Wildl Manage 64:346354

Engel S, Pederson JL (1998) The construction, aesthetics, and effects of lakeshore development: a literature review. Wisconsin Department of Natural Resources Research Report 177: 45 pp

Eriksson BK, Sandström A, Isaeus M, Schreiber H, Karås P (2004) Effects of boating activities on aquatic vegetation in the Stockholm archipelago, Baltic Sea. Estuar Coast Shelf Sci 61:339-349

Everett RA, Ruiz GM (1993) Coarse woody debris as a refuge from predation in aquatic communities. Oecologia 93:475-486

Everson DA, Boucher DH (1998) Tree species richness and topographic complexity along the riparian edge of the Potomac River. For Ecol Manag 109:305-314

Farrell JM (2001) Reproductive success of sympatric northern pike and muskellunge in an upper St. Lawrence River bay. Trans Am Fish Soc 130:796-808

Fladung E (2002) Der präadulte/adulte Fischbestand in Buhnenfeldern und Leitwerken der Mittelelbe. Z Fischkd Suppl 1:101-120

Forbes DL, Taylor RB (1994) Ice in the shore zone and the geomorphology of cold coasts. Prog Phys Geogr 18:59-96

Francis TB, Schindler DE (2006) Degradation of littoral habitats by residential development: woody debris in lakes of the Pacific Northwest and Midwest, United States. Ambio 35:274-280

Fujii T, Raffaelli D (2008) Sea-level rise, expected environmental changes, and responses of intertidal benthic macrofauna in the Humber estuary, UK. Mar Ecol Prog Ser 371:23-35

Gabel F, Garcia X-F, Brauns M, Sukhodolov A, Leszinski M, Pusch MT (2008) Resistance to ship-induced waves of benthic invertebrates in various littoral habitats. Freshw Biol 53:15671578

Garbary DJ, Fraser S, Ferguson C, Lauff RF (2004) Use of eelgrass, Zostera marina, wrack by three species of ladybird beetles (Coleoptera: Coccinellidae) in Prince Edward Island. Can Field Nat 118:225-228

Garland RD, Tiffan KF, Rondorf DW, Clark LO (2002) Comparison of subyearling fall Chinook salmon's use of riprap revetments and unaltered habitats in Lake Wallula of the Columbia River. North Am J Fish Manag 22:1283-1289

Glasby TM, Connell SD (1999) Urban structures as marine habitats. Ambio 28:595-598

Gray LJ (1993) Response of insectivorous birds to emerging aquatic insects in riparian habitats of a tallgrass prairie stream. Am Midl Nat 129:288-300

Gregory KJ, Gurnell AM (1988) Vegetation and river channel form and process. In: Viles HA (ed) Biogeomorphology. Basil Blackwell, Oxford, pp 11-42

Groffman PM, Bain DJ, Band LE, Belt KT, Brush GS, Grove JM, Pouyat RV, Yesilonis IC, Zipperer WC (2003) Down by the riverside: urban riparian ecology. Front Ecol Environ 1:315-321

Guinez R, Pacheco CJ (1999) Maximum wave velocity estimations on the intertidal rocky shore at central Chile, using a prototype dynamometer. Revista Chilena de Historia Natural $72: 251-260$

Gurnell AM (2003) Wood storage and mobility. In: Gregory SV, Boyer KL, Gurnell AM (eds) The Ecology and Management of Wood in World Rivers. American Fisheries Society Symposium, Bethesda, MD, pp 75-91

Gurnell AM, Petts GE (2002) Island-dominated landscapes of large floodplain rivers, a European perspective. Freshw Biol 47:581600

Gurnell A, Tockner K, Edwards P, Petts G (2005) Effects of deposited wood on biocomplexity of river corridors. Front Ecol Environ 3:377-382

Hamilton SK, Sippel SJ, Melack JM (1995) Oxygen depletion and carbon-dioxide and methane production in waters of the Pantanal wetlands of Brazil. Biogeochemistry 30:115-141

Hammerstrom KK, Kenworthy WJ, Whitfield PE, Merell MF (2007) Response and recovery dynamics of seagrasses Thalassia testudinum and Syringodium filiforme and macroalgae in experimental motor vessel disturbances. Mar Ecol Prog Ser 345:83-92

Hecky RE, Smith REH, Barton DR, Guildford SJ, Taylor WD, Charlton MN, Howell T (2004) The nearshore phosphorus shunt: a consequence of ecosystem engineering by dreissenids in the Laurentian Great Lakes. Can J Fish Aquat Sci 61:1285-1293

Hein T, Baranyi C, Reckendorfer W, Schiemer F (2004) The impact of surface water exchange on the nutrient and particle dynamics in side-arms along the River Danube, Austria. Sci Total Environ 328:207-218

Hein T, Reckendorfer W, Thorp JH, Schiemer F (2005) The role of slackwater areas for biogeochemical processes in rehabilitated river corridors: examples from the Danube. Archiv für Hydrobiologie Supplementband 155:425-442

Henschel JR, Mahsberg D, Stumpf H (2001) Allochthonous aquatic insects increase predation and decrease herbivory in river shore food webs. Oikos 93:429-438

Hijmans RJ, Graham CH (2006) The ability of climate envelope models to predict the effect of climate change on species distributions. Glob Chang Biol 12:2272-2281

Hill NM, Keddy PA, Wisheu IC (1998) A hydrological model for predicting the effects of dams on the shoreline vegetation of lakes and reservoirs. Environ Manage 22:723-736

Hirota M, Senga Y, Seike Y, Nohara S, Kunii H (2007) Fluxes of carbon dioxide and nitrous oxide in two contrastive fringing zones of coastal lagoon, Lake Nakaumi, Japan. Chemosphere 68:597-603

Hoffmann A, Hering D (2000) Wood-associated macroinvertebrate fauna in Central European streams. Int Rev Hydrobiol 85:25-48

Hofmann H, Lorke A, Peeters F (2008) The relative importance of wind and ship waves in the littoral zone of a large lake. Limnol Oceanogr 53:368-380

Hostmann M, Borsuk M, Reichert P, Truffer B (2005) Stakeholder values in decision support for river rehabilitation. Archiv für Hydrobiologie Supplementband 155:491-505

Hutchinson GE (1967) A treatise on limnology, volume II: introduction to lake biology and the limnoplankton. Wiley, New York, $1115 \mathrm{pp}$

IPCC (2007) Climate change 2007: synthesis report. Intergovernmental Panel on Climate Change. http://www.ipcc.ch/pdf/assessmentreport/ar4/syr/ar4_syr.pdf. Accessed 5 April 2008

Irlandi EA, Crawford MK (1997) Habitat linkages: the effect of intertidal saltmarshes and adjacent subtidal habitats on abundance, movement, and growth of an estuarine fish. Oecologia 110:222-230

Jackson JK, Huryn AD, Strayer DL, Courtemanch D, Sweeney BW (2005) Atlantic Rivers-Northeastern States. In: Benke AC, Cushing CE (eds) Rivers of North America. Academic Press, San Diego, pp 20-71 
Jansson R, Zinko U, Merritt DM, Nilsson C (2005) Hydrochory increases riparian plant species richness: a comparison between a free-flowing and a regulated river. J Ecol 93:1094-1103

Jedrezejczak MF (2002a) Stranded Zostera marina L. vs. wrack fauna community interactions on a Baltic sandy beach (Hel, Poland): a short-term pilot study. Part I. Driftline effects of fragmented detritivory, leaching, and decay rates. Oceanologia 44:273-286

Jedrezejczak MF (2002b) Stranded Zostera marina L. vs. wrack fauna community interactions on a Baltic sandy beach (Hel, Poland): a short-term pilot study. Part II. Driftline effects of succession changes and colonization of beach fauna. Oceanologia 44:367387

Jenkins GP, Wheatley MJ (1998) The influence of habitat structure on nearshore fish assemblages in a southern Australian embayment: comparison of shallow seagrass, reef-algal and unvegetated sand habitats, with emphasis on their importance to recruitment. J Exp Mar Biol Ecol 221:147-172

Jenkins SR, Moore P, Burrows MT, Garbary DJ, Hawkins SJ, Ingolfsson A, Sebens KP, Snelgrove PVR, Wethey DS, Woodin SA (2008) Comparative ecology of North Atlantic shores: do differences in players matter for process? Ecology 89:S3-S23

Jennings MJ, Bozek MA, Hatzenbeler GR, Emmons EE, Staggs MD (1999) Cumulative effects of incremental shoreline habitat modification on fish assemblages in North Temperate lakes. North Am J Fish Manag 19:18-27

Jenny H (1941) Factors of soil formation: a system of quantitative pedology. McGraw-Hill, New York, 288 pp

Johnson WC (2002) Riparian vegetation diversity along regulated rivers: contribution of novel and relict habitats. Freshw Biol 47:749-759

Jordanova AA, James CS (2003) Experimental study of bed load transport through emergent vegetation. J Hydraul Eng 129:474478

Jungwirth M, Haidvogl G, Hohensinner S, Muhar S, Schmutz S, Waidbacher H (2005) Leitbild-specific measures for the rehabilitation of the heavily modified Austrian Danube River. Archiv für Hydrobiologie Supplementband 155:17-36

Junk WJ, Bayley PB, Sparks RE (1989) The flood pulse concept in river-floodplain systems. Proceedings of the International Large Rivers Symposium. Can Spec Publ Fish Aquat Sci 106:110-127

Juutinen S, Alm J, Larmola T, Huttenen JT, Morero M, Martikainen PJ, Silvola J (2003) Major implication of the littoral zone for methane release from boreal lakes. Global Biogeochem Cycles 17(4):1117. doi:10.1029/2003GB002105

Kankaala P, Ojala A, Käki T (2004) Temporal and spatial variation in methane emissions from a flooded transgression shore of a boreal lake. Biogeochemistry 68:297-311

Keddy PA (1982) Quantifying within-lake gradients of wave energy: interrelationships of wave energy, substrate particle size and shoreline plants in Axe Lake, Ontario. Aquat Bot 14:41-58

Keddy PA (1983) Shoreline vegetation in Axe Lake, Ontario: effects of exposure on zonation patterns. Ecology 64:331-344

Keddy PA, Reznicek AA (1986) Great Lakes vegetation dynamics: the role of fluctuating water levels and buried seeds. J Great Lakes Res 12:25-36

Kennedy CW, Bruno JF (2000) Restriction of the upper distribution of New England cobble beach plants by wave-related disturbance. J Ecol 88:856-868

Kleinwächtler M, Eggers TO, Hennig M, Anlauf A, Hentschel B, Larink O (2005) Distribution patterns of terrestrial and aquatic invertebrates influenced by different groyne forms along the River Elbe (Germany). Archiv für Hydrobiologie Supplementband 155:319-338

Kostylev VE, Erlandsson J, Ming MY, Williams GA (2005) The relative importance of habitat complexity and surface area in assessing biodiversity: fractal application on rocky shores. Ecol Complex 2:272-286

Kraufvelin P, Salovius S (2004) Animal diversity in Baltic rocky shore macroalgae: can Cladophora glomerata compensate for lost Fucus vesiculosus? Estuar Coast Shelf Sci 61:369-378

Kraufvelin P, Moy FE, Christie H, Bokn TL (2006) Nutrient addition to experimental rocky shore communities revisited: delayed responses, rapid recovery. Ecosystems 9:1076-1093

Langhans SD, Tockner K (2006) The role of timing, duration, and frequency of inundation in controlling leaf litter decomposition in a river-floodplain ecosystem (Tagliamento, northeastern Italy). Oecologia 147:501-509

Lavalle PD, Lakhan VC (2000) An assessment of lake-level fluctuations on beach and shoreline changes. Coastal Manage 28:161-173

Le Hir M, Hily C (2005) Macrofaunal diversity and habitat structure in intertidal boulder fields. Biodivers Conserv 14:233-250

Leopold LB, Wolman MG, Miller JP (1964) Fluvial processes in geomorphology. W.H. Freeman, San Francisco, 522 pp

Lewin W-C, Okun N, Mehner T (2004) Determinants of the distribution of juvenile fish in the littoral area of a shallow lake. Freshw Biol 49:410-424

Lico MS (2004) Gasoline-related organics in Lake Tahoe before and after prohibition of carbureted two-stroke engines. Lake Reserv Manage 20:164-174

Lockwood JL, Hoopes MF, Marchetti MP (2007) Invasion ecology, Blackwell, Malden, $312 \mathrm{pp}$

Lodge DM, Williams S, MacIsaac HJ, Hayes KR, Leung B, Reichard S, Mack RN, Moyle PB, Smith M, Andow DA, Carlton JT, McMichael A (2006) Biological invasions: Recommendations for U.S. policy and management. Ecol Appl 16:2035-2054

Long JM, Walker DJ (2005) Small scale application and assessment of an Index of Biotic Integrity for a large boreal river. Hydrobiologia 544:177-187

Lorang MS, Komar PD, Stanford JA (1993) Lake level regulation and shoreline erosion on Flathead Lake, Montana-a response to the redistribution of annual wave energy. J Coastal Res 9:494508

Lovett GM, Jones CG, Turner MG, Weathers KC (eds) (2005) Ecosystem function in heterogeneous landscapes. Springer, New York, $489 \mathrm{pp}$

Lowrance R (1998) Riparian forest ecosystems as filters for nonpointsource pollution. In: Pace ML, Groffman PM (eds) Successes, Limitations, and Frontiers in Ecosystem Science. Springer, New York, pp 113-141

Ludwig DF, Iannuzzi TJ (2006) Habitat equivalency in urban estuaries: an analytical hierarchy process for planning ecological restoration. Urban Ecosyst 9:265-290

Maccarone AD, Brzorad JD, Parsons KC (1993) Nest site selection by herring gulls in an urban estuary. Colon Waterbirds 16:216-220

MacRae PSD, Jackson DA (2001) The influence of smallmouth bass (Micropterus dolomieu) predation and habitat complexity on the structure of littoral zone fish assemblages. Can J Fish Aquat Sci $58: 342-351$

Madjeczak JC, Mundahl ND, Lehtinen RM (1998) Fish assemblages of natural and artificial habitats within the channel border of the upper Mississippi River. Am Midl Nat 139:296-310

Magoulick DD (1998) Effect of wood hardness, condition, texture and substrate type on community structure of stream invertebrates. Am Midl Nat 139:187-200

Malm T, Råberg S, Fell S, Carlsson P (2004) Effects of beach cast cleaning on beach quality, microbial food web, and littoral macrofaunal biodiversity. Estuar Coast Shelf Sci 60:339-347

Mandelbrot B (1967) How long is the coast of Britain? Statistical selfsimilarity and fractional dimension. Science 156:636-638 
Marburg AE, Turner MG, Kratz TK (2006) Natural and anthropogenic variation in coarse wood among and within lakes. J Ecol 94:558-568

Marsden ID (1991) Kelp-sandhopper interactions on a sand beach in New Zealand. I. Drift composition and distribution. J Exp Mar Biol Ecol 152:61-74

Martin D, Bertasi F, Colangelo MA, de Vries M, Frost M, Hawkins SJ, Macpherson E, Moschella PS, Satta MP, Thompson RC, Ceccherelli VU (2005) Ecological impact of coastal defence structures on sediment and mobile fauna: evaluating and forecasting consequences of unavoidable modifications of native habitats. Coast Eng 52:1027-1052

McClain ME, Boyer EW, Dent CL, Gergel SE, Grimm NB, Groffman PM, Hart SC, Harvey JW, Johnston CA, Mayorga E, McDowell WH, Pinay G (2003) Biogeochemical hot spots and hot moments are the interface of terrestrial and aquatic ecosystems. Ecosystems 6:301-312

McClintock JB, Angus RA, McClintock FE (2007) Abundance, diversity, and fidelity of macroinvertebrates sheltering beneath rocks during tidal emersion in an intertidal cobble field: does the intermediate disturbance hypothesis hold for less exposed shores with smaller rocks? J Exp Mar Biol Ecol 352:351-360

McLachlan A (1983) Sandy beach ecology-a review. In: McLachlan A, Erasmus T (eds) Sandy Beaches as Ecosystems, Developments in Hydrobiology 19. W. Junk, The Hague, pp 321-380

McLachlan A (1985) The biomass of macro- and interstitial fauna on clean and wrack-covered beaches in western Australia. Estuar Coast Shelf Sci 21:587-599

McLachlan A, Brown AC (2006) The ecology of sandy shores, 2nd edn. Academic Press, San Diego, 392 pp

McNaughton SJ, Oesterheld M, Frank DA, Williams KJ (1991) Relationships between primary and secondary production in terrestrial ecosystems. In: Cole JJ, Lovett GM, Findlay S (eds) Comparative Analyses of Ecosystems: Patterns, Mechanisms, and Theories. Springer-Verlag, New York, pp 120-139

Meadows GA, Mackey SD, Goforth RR, Mickelson DM, Edil TB, Fuller J, Guy DE, Meadows LA, Brown E, Carman SM, Liebenthal DL (2005) Cumulative habitat impacts of nearshore engineering. J Great Lakes Res 31(Supplement 1):90-112

Miles JR, Russell PE (2004) Dynamics of a reflective beach with a low tide terrace. Cont Shelf Res 24:1219-1247

Miles JR, Russell PE, Huntley DA (2001) Field measurements of sediment dynamics in front of a seawall. J Coastal Res 17:195206

Miller D, Ladd J, Nieder WC (2006) Channel morphology in the Hudson River Estuary: Historical changes and opportunities for restoration. In: Waldman JR, Limburg KE, Strayer DL (eds) Hudson river fishes and their environment. American Fisheries Society Symposium, Bethesda, pp 29-37

Minchinton TE (2002) Disturbance by wrack facilitates spread of Phragmites australis in a coastal marsh. J Exp Mar Biol Ecol 281:89-107

Minchinton TE (2006) Rafting on wrack as a mode of dispersal for plants in coastal marshes. Aquat Bot 84:372-376

Mitsch WJ, Gosselink JG (2007) Wetlands, 4th edn. Wiley, New York, $600 \mathrm{pp}$

Moon HP (1934) An investigation of the littoral fauna of Windermere. J Anim Ecol 3:8-28

Moon HP (1935) Flood movements of the littoral fauna of Windermere. J Anim Ecol 4:216-228

Moore PG (2002) Mammals in intertidal and maritime ecosystems: interactions, impacts and implications. Oceanogr Mar Biol Annu Rev 40:491-608

Moreira J, Chapman MG, Underwood AJ (2006) Seawalls do not sustain viable populations of limpets. Mar Ecol Prog Ser 322:179-188
Moschella PS, Abbiati M, Aberg P, Airoldi L, Anderson JM, Bacchiocchi F, Bulleri F, Dinesen GE, Frost M, Gacia E, Granhag L, Jonsson PR, Satta MP, Sundelof A, Thompson RC, Hawkins SJ (2005) Low-crested coastal defence structures as artificial habitats for marine life: using ecological criteria in design. Coast Eng 52:1053-1071

Naiman RJ, Bilby RE, Schindler DE, Helfield JM (2002) Pacific salmon, nutrients, and the dynamics of freshwater and riparian ecosystems. Ecosystems 5:399-417

Naiman RJ, Décamps H, McClain ME (2005) Riparia: ecology, conservation, and management of streamside communities. Elsevier, Amsterdam, $448 \mathrm{pp}$

National Research Council (2007) Mitigating shore erosion along sheltered coasts. The National Academies Press, Washington, $174 \mathrm{pp}$

Neuman KK, Henkel LA, Page GW (2008) Shorebird use of sandy beaches in central California. Waterbirds 31:115-121

Nicholls RJ, Hoozemans FMJ, Marchand M (1999) Increasing flood risk and wetland losses due to global sea-level rise: regional and global analyses. Global Environmental Change 9:S69-S87

Nilsson C, Svedmark M (2002) Basic principles and ecological consequences of changing water regimes: riparian plant communities. Environ Manage 30:468-480

Nilsson C, Ekblad A, Gardfjell M, Carlberg B (1991) Long-term effects of river regulation on river margin vegetation. J Appl Ecol 28:963-987

Nishihiro J, Araki S, Fujiwara N, Washitani I (2004) Germination characteristics of lakeshore plants under an artificially stabilized water regime. Aquat Bot 79:333-343

NOAA (2008) Historic Great Lakes water level data. http:// tidesandcurrents.noaa.gov/station_retrieve.shtml?type=Historic + Great+Lakes+Water+Level+Data. Accessed 3 April 2008

O'Donnell MJ (2008) Reduction in wave forces within bare patches in mussel beds. Mar Ecol Prog Ser 362:157-167

Obrdlík P, Faulkner G, Castella E (1995) Biodiversity of Gastropoda in European floodplains. Archiv für Hydrobiologie Supplementband 101:339-356

Olden JD, Poff NL (2003) Redundancy and the choice of hydrologic indices for characterizing streamflow regimes. River Res Appl 19:101-121

Orr M, Zimmer M, Jelinski DE, Mews M (2005) Wrack deposition on different beach types: spatial and temporal variation in the pattern of subsidy. Ecology 86:1496-1507

Ostendorp W (2004) New approaches to integrated quality assessment of lakeshores. Limnologica 34:160-166

Ostendorp W (2008) Evaluierung von 90 Uferrenaturierungsmassnahnen am Bodensee. WasserWirtschaft 12:31-35

Ostendorp W, Schmieder K, Jöhnk K (2004) Assessment of human pressures and their hydromorphological impacts on lakeshores in Europe. Ecohydrology and Hydrobiology 4:379-395

Paetzold A, Tockner K (2005) Effects of riparian arthropod predation on the biomass and abundance of aquatic insect emergence. $\mathrm{J}$ North Am Benthol Soc 24:395-402

Paetzold A, Schubert CJ, Tockner K (2005) Aquatic-terrestrial linkages along a braided river: riparian arthropods feeding on aquatic insects. Ecosystems 8:748-759

Paetzold A, Lee M, Post DM (2008a) Marine resource flows to terrestrial arthropod predators on a temperate island: the role of subsidies between systems of similar productivity. Oecologia 157:653-659

Paetzold A, Yoshimura C, Tockner K (2008b) Riparian arthropod responses to flow regulation and river channelization. J Appl Ecol 45:894-903

Paine RT (1994) Marine rocky shores and community ecology: an experimentalist's perspective. Ecology Institute, Oldendorf/ Luhe, Germany, $152 \mathrm{pp}$ 
Pennings SC, Carefoot TH, Zimmer M, Danko JP, Ziegler A (2000) Feeding preferences of supralittoral isopods and amphipods. Can J Zool 78:1918-1929

Petticrew EL, Kalff J (1991) Calibration of a gypsum source for freshwater flow measurements. Can J Fish Aquat Sci 48:1244-1249

Pieczyńska E (1972) Ecology of the eulittoral zone of lakes. Ekologia Polska 20:637-732

Piégay H (2003) Dynamics of wood in large rivers. In: Gregory SV, Boyer KL, Gurnell AM (eds) The ecology and management of wood in World rivers. American Fisheries Society Symposium, Bethesda, pp 109-133

Pilkey OH, Young RS, Riggs SR, Smith AWS, Wu H, Pilkey WD (1993) The concept of shoreface profile of equilibrium: a critical review. J Coastal Res 9:255-278

Pinn EH, Rodgers M (2005) The influence of visitors on intertidal biodiversity. J Mar Biol Assoc UK 85:263-268

Planty-Tabacchi A-M, Tabacchi E, Naiman RJ, Deferrari C, Decamps $\mathrm{H}$ (1996) Invasibility of species-rich communities in riparian zones. Conserv Biol 10:598-607

Poff NL, Allan JD, Bain MB, Karr JR, Prestegaard KL, Richter BD, Sparks RE, Stromberg JC (1997) The natural flow regime. Bioscience 47:769-784

Polis GA, Hurd SD (1996) Linking marine and terrestrial food webs: allochthonous input from the ocean supports high secondary productivity on small islands and coastal land communities. American Naturalist 147:396-423

Pollock MM, Naiman RJ, Hanley TA (1998) Plant species richness in riparian wetlands: a test of biodiversity theory. Ecology 79:94105

Porter ET, Sanford LP, Suttles SE (2000) Gypsum dissolution is not a universal integrator of 'water motion'. Limnol Oceanogr 45:145-158

Povey A, Keough MJ (1991) Effects of trampling on plant and animal populations on rocky shores. Oikos 61:355-368

Power ME (1984) Depth distributions of armored catfish: predatorinduced resource avoidance? Ecology 65:523-528

Power ME, Dudley TL, Cooper SD (1989) Grazing catfish, fishing birds, and attached algae in a Panamanian stream. Environ Biol Fish 26:285-294

Pugh PJA, Davenport J (1997) Colonisation vs. disturbance: the effects of sustained ice-scouring on intertidal communities. J Exp Mar Biol Ecol 210:1-21

Puijalon S, Lena JP, Riviere N, Champagne JY, Rostan JC, Bornette G (2008) Phenotypic plasticity in response to mechanical stress: hydrodynamic performance and fitness of four aquatic plant species. New Phytol 177:907-917

Pyšek P, Prach K (1993) Plant invasions and the role of riparian habitats: a comparison of four species alien to central Europe. J Biogeogr 20:413-420

Quist MC, Tillma JS, Burlingame MN, Guy CS (1999) Overwinter habitat use of shovelnose sturgeon in the Kansas River. Trans Am Fish Soc 128:522-527

Radomski P, Goeman TJ (2001) Consequences of human lakeshore development on emergent and floating-leaf vegetation abundance. North Am J Fish Manag 21:46-61

Reichard M, Jurajda P, Smith C (2004) Spatial distribution of drifting cyprinid fishes in a shallow lowland river. Archiv für Hydrobiologie 159:395-407

Reichert P, Borsuk M, Hostmann M, Schweizer S, Spörri C, Tockner K, Truffer B (2007) Concepts of decision support for river rehabilitation. Environmental Monitoring and Software 22:188201

Reimnitz E, Hayden E, McCormick M, Barnes PW (1991) Preliminary observations on coastal sediment loss through icerafting in Lake Michigan. J Coastal Res 7:653-664
Rejmánek M, Richardson DM, Higgins SI, Pitcairn MJ, Grotkopp E (2005) Ecology of invasive plants: state of the art. In: Mooney HA, Mack RN, McNeely JA, Neville LE, Schei PJ, Waage JK (eds) Invasive Alien Species: A New Synthesis. Island Press, Washington, DC, pp 104-161

Rempel LL, Richardson JS, Healey MC (1999) Flow refugia for benthic macroinvertebrates during flooding of a large river. J North Am Benthol Soc 18:34-48

Rich C, Longcore T (eds) (2005) Ecological consequences of artificial night lighting. Island Press, Washington, $458 \mathrm{pp}$

Richter BD, Baumgartner JV, Powell J, Braun DP (1996) A method for assessing hydrologic alteration within ecosystems. Conserv Biol 10:1163-1174

Riis T, Hawes I (2003) Effect of wave exposure on vegetation abundance, richness and depth distribution of shallow water plants in a New Zealand lake. Freshw Biol 48:75-87

Robinson CT, Tockner K, Ward JV (2002) The fauna of dynamic riverine landscapes. Freshw Biol 47:661-677

Rodgers JA, Schwikert ST (2002) Buffer-zone distances to protect foraging and loafing waterbirds from disturbance by personal watercraft and outboard-powered boats. Conserv Biol 16:219224

Rodrigues AM, Meireles S, Pereira T, Gama A, Quintino V (2006) Spatial patterns of benthic macroinvertebrates in intertidal areas of a southern European estuary: the Tagus, Portugal. Hydrobiologia 555:99-113

Romanuk TA, Levings CN (2003) Associations between arthropods and the supralittoral ecotone: dependence of aquatic and terrestrial taxa on riparian vegetation. Environ Entomol 32:1343-1353

Rosenberger EE, Hampton SE, Fradkin SC, Kennedy BP (2008) Effects of shoreline development on the nearshore environment in large deep oligotrophic lakes. Freshw Biol 53:1673-1691

Rossi F, Underwood AJ (2002) Small-scale disturbance and increased nutrients as influences on intertidal macrobenthic assemblages: experimental burial of wrack in different intertidal environments. Mar Ecol Prog Ser 241:29-39

Rossi F, Forster RM, Montserrat F, Ponti M, Terlizzi A, Ysebaert T, Middelburg JJ (2007) Human trampling as short-term disturbance on intertidal mudflats: effects on macrofauna biodiversity and population dynamics of bivalves. Mar Biol 151:2077-2090

Sabo JL, Post DM (2008) Quantifying periodic, stochastic, and catastrophic environmental variation. Ecol Monogr 78:19-40

Salovius S, Kraufvelin P (2004) The filamentous green alga Cladophora glomerata as a habitat for littoral macrofauna in the northern Baltic Sea. Ophelia 58:65-78

Salovius S, Nyqvist M, Bonsdorff E (2005) Life in the fast land: macrobenthos use temporary drifting algal habitats. J Sea Res 53:169-180

Sandström A, Eriksson BK, Karås P, Isaeus M, Schreiber H (2005) Boating and navigation activities influence the recruitment of fish in a Baltic Sea archipelago area. Ambio 34:125-130

Šapkarev JA (1975) Composition and dynamics of the bottom animals in the littoral zone of Dojran Lake, Macedonia. Verhandlungen der Internationale Vereinigung für Theoretische und Angewandte Limnologie 19:1339-1350

Sass GG, Kitchell JF, Carpenter SR, Hrabik TR, Marburg AE, Turner MG (2006) Fish community and food web responses to a wholelake removal of coarse woody habitat. Fisheries 31:321-330

Schindler DE, Geib SI, Williams MR (2000) Patterns of fish growth along a residential development gradient in North Temperate lakes. Ecosystems 3:229-237

Schlacher TA, Richardson D, McLean I (2008a) Impacts of off-road vehicles (ORVs) on macrobenthic assemblages on sandy beaches. Environ Manage 41:878-892 
Schlacher TA, Thompson LMC, Walker SJ (2008b) Mortalities caused by off-road vehicles (ORVs) to a key member of sandy beach assemblages, the surf clam Donax deltoids. Hydrobiologia 610:345-350

Schmieder K (2004) European lake shores in danger-concepts for a sustainable development. Limnologica 34:3-14

Scholten M (2002) Das Jungfischaufkommen in Uferstrukturen des Hauptstroms der mittleren Elbe-zeitliche und räumlich Dynamik. Zeitschrift für Fischkunde Supplementband 1:59-77

Scholten M, Anlauf A, Büchele B, Faulhaber P, Henle K, Kofalk S, Leyer I, Meyerhoff J, Purps J, Rast G, Scholz M (2005) The River Elbe in Germany-present state, conflicting goals, and perspectives of rehabilitation. Archiv für Hydrobiologie Supplementband 155:579-602

Sedell JR, Froggatt JL (1984) Importance of streamside forests to large rivers: the isolation of the Willamette River, Oregon, U.S.A., from its floodplain by snagging and streamside forest removal. Verhandlungen der Internationale Vereinigung für Theoretische und Angewandte Limnologie 22:1828-1834

Short AD (1996) The role of wave height, period, slope, tide range and embaymentisation in beach classifications: a review. Revista Chilena de Historia Natural 69:589-604

Smith JW, Renken RB (1991) Least tern nesting habitat in the Mississippi River valley adjacent to Missouri. J Field Ornithol 62:497-504

Smith M, Keevin T, Mettler-McClure P, Barkau R (1998) Effect of the flood of 1993 on Boltonia decurrens, a rare floodplain plant. Regul Rivers Res Manage 14:191-202

Smith RJ, Hamas MJ, Ewert DN, Dallman ME (2004) Spatial foraging differences in American redstarts along the shoreline of northern Lake Huron during spring migration. Wilson Bull 116:48-55

Smith RJ, Moore FR, May CA (2007) Stopover habitat along the shoreline of northern Lake Huron, Michigan: emergent aquatic insects as a food resource for spring migrating landbirds. Auk 124:107-121

Sorrell BK, Mendelsson IA, McKee KL, Woods RA (2000) Ecophysiology of wetland plant roots: a modelling comparison of aeration in relation to species distribution. Ann Bot 86:675-685

Steel EA, Richards WH, Kelsey KA (2003) Wood and wildlife: benefits of river wood to terrestrial and aquatic vertebrates. In: Gregory SV, Boyer KL, Gurnell AM (eds) The Ecology and Management of Wood in World Rivers. American Fisheries Society Symposium, Bethesda, MD, pp 235-247

Stickney AA, Anderson BA, Ritchie RJ, King JG (2002) Spatial distribution, habitat characteristics and nest-site selection by tundra swans on the Central Arctic Coastal Plain, northern Alaska. Waterbirds 25:227-235

Stolen ED (2003) The effects of vehicle passage on foraging behavior of wading birds. Waterbirds 26:429-436

Strang I, Dienst M (2004) Die Auswirkungen der Wasserstände am Bodensee auf des Deschampsietum rhenanae zwischen 1989 und 2003. Limnologica 34:22-28

Strayer DL, Smith LC (2000) Macroinvertebrates of a rocky shore in the freshwater tidal Hudson River. Estuaries 23:359-366

Strayer DL, Lutz C, Malcom HM, Munger K, Shaw WH (2003) Invertebrate communities associated with a native (Vallisneria americana) and an alien (Trapa natans) macrophyte in a large river. Freshw Biol 48:1938-1949

Sweeney BW (1993) Effects of streamside vegetation on macroinvertebrate communities of White Clay Creek in eastern North America. Proc Acad Nat Sci Phila 144:291-340

Tabacchi E, Tabacchi-Planty AM, Salinas MJ, Decamps H (1996) Landscape structure and diversity in riparian plant communities: a longitudinal comparative study. Regul Rivers Res Manage $12: 367-390$
Thiel M, Gutow L (2005) The ecology of rafting in the marine environment-I: The floating substrata. Oceanogr Mar Biol Annu Rev 42:181-263

Thompson TL, Glenn EP (1994) Plaster standards to measure water motion. Limnol Oceanogr 39:1768-1779

Thompson RC, Crowe TP, Hawkins SJ (2002) Rocky intertidal communities: past environmental changes, present status and predictions for the next 25 years. Environ Conserv 29:168-191

Thompson RC, Olsen Y, Mitchell RP, Davis A, Rowland SJ, John AWG, McGonigle D, Russell AE (2004) Lost at sea: where is all the plastic? Science $304: 838$

Thoms MC (2003) Floodplain-river ecosystems: lateral connections and the implications of human interference. Geomorphology 56:335-349

Tockner K, Stanford JA (2002) Riverine floodplains: present state and future trends. Environ Conserv 29:308-330

Toft JD, Cordell JR, Simonstad CA, Stamation LA (2007) Fish distribution, abundance, and behavior along city shoreline types in Puget Sound. North Am J Fish Manag 27:465-480

Tolley PM, Christian RR (1999) Effects of increased inundation and wrack deposition on a high salt marsh plant community. Estuaries 22:944-954

Trulio LA, Sokale J (2008) Foraging shorebird response to trail use around San Francisco Bay. J Wildl Manage 72:1775-1780

USGS (2009a) National water information system: web interface, USGS 01372058 Hudson River below Poughkeepsie NY. Accessed 23 February 2009

USGS (2009b) National water information system: web interface, USGS 06054500 Missouri River at Toston MT. Accessed 1 September 2009

Van der Zande AN, Vos P (1984) Impact of a semi-experimental increase in recreation intensity on the densities of birds in groves and hedges on a lake shore in The Netherlands. Biol Conserv 30:237-259

Van Geest GJ, Coops H, Roijackers RMM, Buijse AD, Scheffer M (2005) Succession of aquatic vegetation driven by reduced waterlevel fluctuations in floodplain lakes. J Appl Ecol 42:251-260

Vogele LE, Rainwater WC (1975) Use of brush shelters as cover by spawning black basses (Micropterus) in Bull Shoals Reservoir. Trans Am Fish Soc 104:264-270

Walker KF, Boulton AJ, Thoms MC, Sheldon F (1994) Effects of water-level changes induced by weirs on the distribution of littoral plants along the River Murray, South Australia. Aust J Mar Freshw Res 45:1421-1438

Wallace JB, Eggert SL, Meyer JL, Webster JR (1999) Effects of resource limitation on a detrital-based ecosystem. Ecol Monogr 69:409-442

Wang FY, Tessier A, Hare L (2001) Oxygen measurements in the burrows of freshwater insects. Freshw Biol 46:317-327

Wantzen KM, Rothhaupt K-O, Mörtl M, Cantonati M, Tóth LG, Fischer P (eds) (2008) Ecological effects of water-level fluctuations in lakes. Hydrobiologia 613:1-184

Ward JV, Tockner K (2001) Biodiversity: towards a unifying theme for river ecology. Freshw Biol 46:807-819

Wetzel RG (1990) Land-water interfaces: metabolic and limnological regulators. Verhandlungen der Internationale Vereinigung für Theoretische und Angewandte Limnologie 24:6-24

Wetzel RG (2001) Limnology: lake and river ecosystems, 3rd edn, Academic Press, San Diego, 1006 pp

Widdows J, Pope ND, Brinsley MD (2008) Effects of Spartina anglica stems on near-bed hydrodynamics, sediment erodability and morphological changes on an intertidal mudflat. Mar Ecol Prog Ser 362:45-57

Wigand C, Stevenson JC, Cornwell JC (1997) Effects of different submersed macrophytes on sediment biogeochemistry. Aquat Bot 56:233-244 
Wilcox DA, Meeker JE (1992) Implications for faunal habitat related to altered macrophyte structure in regulated lakes in northern Minnesota. Wetlands 12:192-203

Wills TC, Bremigan MT, Hayes DB (2004) Variable effects of habitat enhancement structures across species and habitats in Michigan reservoirs. Trans Am Fish Soc 133:399-411

Winfield IJ (2004) Fish in the littoral zone: ecology, threats and management. Limnologica 34:124-131

Winn PJS, Edwards AMC, Young RM, Waters R, Lunn J (2005) A strategic approach to flood defence and habitat restoration for the Humber estuary. Archiv für Hydrobiologie Supplementband 155:631-641

Wolter C, Arlinghaus R (2003) Navigation impacts on freshwater fish assemblages: the ecological relevance of swimming performance. Rev Fish Biol Fisheries 13:63-89
Wondzell SM, Bisson PA (2003) Influence of wood on aquatic biodiversity. In: Gregory SV, Boyer KL, Gurnell AM (eds) The Ecology and Management of Wood in World Rivers. American Fisheries Society Symposium, Bethesda, MD, pp 249-263

Zalewski M, Lapinska M, Bayley PB (2003) Fish relationships with wood in large rivers. In: Gregory SV, Boyer KL, Gurnell AM (eds) The Ecology and Management of Wood in World Rivers. American Fisheries Society Symposium, Bethesda, MD, pp 195211

Zhu S, Chang AT (2001) Investigations on the reflective behaviour of a slotted seawall. Coast Eng 43:93-104 